\title{
Historical, hydraulic, hydrological and meteorological reconstruction of 1874 Santa Tecla flash floods in Catalonia (NE Iberian Peninsula)
}

\author{
Josep Lluís Ruiz-Bellete,*, Josep Carles Balasch ${ }^{\mathrm{a}}$, Jordi Tuset ${ }^{\mathrm{b}, \mathrm{c}}$, Mariano \\ Barriendos $^{\mathrm{d}}$, Jordi Mazon ${ }^{\mathrm{e}}$, David Pino ${ }^{\mathrm{e}, \mathrm{f}}$ \\ ${ }^{a}$ Department of Environment and Soil Sciences, University of Lleida, Lleida, Spain \\ ${ }^{b}$ Forest Science Centre of Catalonia, Solsona, Spain \\ ${ }^{c}$ RIUS Fluvial Dynamics Research Group, University of Lleida, Lleida, Spain \\ ${ }^{d}$ Department of Modern History, University of Barcelona, Barcelona, Spain \\ ${ }^{e}$ Department of Applied Physics, Universitat Politècnica de Catalunya.BarcelonaTech, \\ Castelldefels, Spain \\ ${ }^{f}$ Institute of Space Studies of Catalonia (IEEC-UPC), Barcelona, Spain
}

\begin{abstract}
A multidisciplinary methodology for historical floods reconstruction was applied to 1874 Santa Tecla floods occurred in Catalonia (NE Iberian Peninsula), using both historical information and meteorological data from 20th Century Reanalysis.
\end{abstract}

The results confirmed the exceptionality of the event: the highest modeled specific peak flow was around $14.6 \mathrm{~m}^{3} \mathrm{~s}^{-1} \mathrm{~km}^{-2}$ in a $100 \mathrm{~km}^{2}$ catchment and all the modeled total rainfall values were above $110 \mathrm{~mm}$ in about six hours, with maximum intensities around $60 \mathrm{~mm} \mathrm{~min}^{-1}$. The peak-flows return periods were about 260 years and the rainfalls periods were between 250 and 500 years. The meteorological cause of the rainstorms was the flash triggering effect, initiated by the withdrawal of a mass of hot air at mid-levels.

\footnotetext{
${ }^{*}$ Corresponding author

Email address: jruizbellet@gmail.com (Josep Lluís Ruiz-Bellet)
}

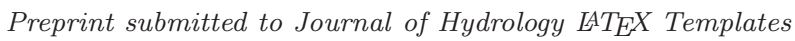

February 5, 2015

(C) 2015. This manuscript version is made available under the Elsevier user license http://www.elsevier.com/open-access/userlicense/1.0/ 
A sensitivity analysis on the various sources of error shows that peak flow errors from hydraulic modeling ranged from 5 to $44 \%$, and rainfall errors from hydrological modeling were about $36 \%$.

Keywords: historical floods, flash floods, multidisciplinary reconstruction, peak flow, rainfall, 20th Century Reanalysis, uncertainty

\section{Introduction}

Flash floods rank among the most dangerous and destructive natural hazards in southern Europe. In spite of this, scientific research about past floods is only recent and mainly focused on modern events. This is a drawback when trying to 5 analyze and classify flash floods in a climatic change context because important information, which old events would provide, is missing.

Fortunately, data about long-past floods can be retrieved from paleographic and dendrogeomorphological evidences and from historical documents. Indeed, historical archives keep raw data -such as maximum water depths, rainfall durations, channel morphologies, atmospheric variables- which, after proper collecting and processing, can enlarge present day records of floods. As said above, the use of this historical information in flood analysis and reconstruction is only very recent and usually restricted to academic research (Bayliss \& Reed, 2001; Benito et al., 2004; Gaume et al., 2004; Naulet et al., 2005; Brázdil et al.,

15 2006; Elleder, 2010), but it will most probably become more used because of the EU Directive 2007/60/EC (2007) on flood risk assessment. 
Nevertheless, only a few studies so far have tried to thoroughly analyze historical floods by linking hydrological and meteorological information (Petersen et al., 1999; Delrieu et al., 2005; Bürger et al., 2006; Flesch \& Reuter, 2012). In this 20 same line, this study presents an applied example of the multidisciplinary methodology (historiographical, hydraulic, hydrological and meteorological) of historical floods reconstruction introduced by Barriendos et al. (2014).

This methodology was applied on a case study: 1874 Santa Tecla floods. The night of 22-23 September 1874 several flash floods occurred in many catchments throughout the eastern part of the Ebro River basin, in Catalonia (NE Iberian Peninsula, Figure 1). These floods -known as Santa Tecla floods because this was the saint of that day- caused 575 casualties and ravaged an approximate area of $10000 \mathrm{~km}^{2}$ and are considered, as a whole, one of the heaviest events in the region in the last 500 years.

Luckily, there is a lot of information about this event, especially, maximum water depths in many locations. So far, some of this information has already been used to calculate the peak flows of the floods in six spots located in three catchments (Balasch et al., 2010a, 2011). Here, we enlarged this list with four more sites and two more catchments. In some cases, it was also possible to calculate the hyetograph of the rainfall. Besides this hydraulic and hydrological information, meteorological data of the days before the floods, available from NOAA's 20th Century Reanalysis (Compo et al., 2011), were used to determine the meteorological causes of the floods.

In summary, the objective of this paper was to use a multidisciplinary 
methodology of hydraulic, hydrological and meteorological reconstruction of historical floods on a study case: the 1874 Santa Tecla floods, occurred in NE Iberian Peninsula.

Although in this paper only this one flood was reconstructed, our long-term objective is to use this multidisciplinary methodology to analyze the heaviest floods occurred in NE Iberian Peninsula in the last 500 years. By doing so with such a thorough reconstruction methodology, we will be able to classify the historical floods of the region according to their meteorological causes and, thus, to improve prediction, planning and readiness.

\section{Study area}

Heavy rainstorms are frequent in NE Iberian Peninsula. The region has a complex orography with a maximum altitude of around $1200 \mathrm{~m}$, which plays a main role in uplifting the Mediterranean air flows thus causing severe storms (Romero et al., 1997; Pascual et al., 2004).

Additionally, its location on the western coast of the Mediterranean basin (Figure 1) favors torrential rainfall, especially at the end of summer and autumn (Llasat et al., 2005), when the warm Mediterranean Sea provides large amounts of heat and moisture to the lower layers of the atmosphere. Moreover, regional climate models forecast a decrease in the average yearly precipitation but, at the same time, an increase in the maximum daily precipitation over this region in this next century (Barrera \& Cunillera, 2011).

The complex orography mentioned above implies small catchments (80-300 
$\left.\mathrm{km}^{2}\right)$ with short, steep streams (15-35 km long and 1-2\% of slope) and, therefore, with a very quick hydrological response: their very low average flows, less than $1 \mathrm{~m}^{3} \mathrm{~s}^{-1}$, can multiply thousands of times in a matter of hours. These 65 catchments, mostly rural but with some populated towns, were the most damaged by 1874 Santa Tecla flash floods, within the $10000 \mathrm{~km}^{2}$ affected area.

The hydraulic and hydrological modeling were performed in ten sites along five different rivers, located in the northern half of the affected area, which are, from north to south and from west to east: Sió, Ondara, Corb, Vall Major and Francolí (Figure 1 and Table 1). All of them have their headwaters either on the Catalan Central Depression ranges or on the Pre-coastal ranges, between 700 and $900 \mathrm{~m}$ (Portella, Tallat, Llena, and Prades ranges). All of them but Francolí flow westwards: Sió and Vall Major into the Segre River, the main tributary of the Ebro River, and Ondara and Corb into large alluvial fans. Francolí flows southwards into the Mediterranean Sea.

All of them have scarce flows all year round, with a high-water period around May and long low-water periods, but, due to irrigation, they never dry up, except Vall Major, which is usually dry. In any case, autumn overflowing flash floods are typical, occurring about three or four times per century (Corominas, 1985; Novoa, 1987; Coma, 1990).

The geological substrates in these catchments are Cenozoic sediments of the Ebro depression, with some outcrops of Paleozoic and Mesozoic materials of the Pre-coastal ranges in the Francolí catchment. The climate is continental Mediterranean with less than $600 \mathrm{~mm}$ of rainfall per year, which decreases as 
height decreases. The main soil use is dry land cereal farming, whereas the higher areas are covered with Mediterranean forest.

\section{Methods}

The reconstruction of a historical flood is the calculation of the event's characteristics from indirect information.

The procedure used to reconstruct 1874 Santa Tecla floods consists of four different steps: the historiographical research, the hydraulic modeling, the hydrological modeling, and the meteorological analysis (Barriendos et al., 2014).

This four steps are linked, because the historiographical research feeds other steps with data, because the results of the hydraulic modeling are the input data of the hydrological modeling, and because the results of the hydrological modeling and the meteorological analysis should qualitatively agree between them and with the meteorological information found in the historiographical research (Figure 2).

It is worth noting the different space scales involved in the hydraulic, hydrological and meteorological reconstructions: typically, the hydraulic reconstruction takes place along a river reach (up to a dozen $\mathrm{km}^{2}$ ); whereas the hydrological one takes into account the whole catchment or a part of it (from some dozens to thousands of $\mathrm{km}^{2}$ ); and the meteorological reconstruction is done, depending on the meteorological phenomenon causing the event, from a local (hundreds of 


\subsection{Historiographical research}

Historiographical research is the key step in the reconstruction of any historical flood: without correct, reliable information, no correct, reliable modeling can be done.

Historiographical research is mainly based in archive scanning, that is, in the systematic scrutiny of documents in search of any records related to any flood. These documents can hold all kinds of data about the flood: meteorological (start and end times of the rainfall, weather in the previous days), hydraulic and hydrological (time of the peak flow, time of the overbank flow, maximum height reached by the water, height of the water at various times, state of saturation of the catchment's soils), and human and social (number of victims, economic loss). Some of these data are essential in order to reconstruct the flood, and the nature of these documents is mostly official (town council's minutes, notarized documents, local authorities official reports to higher levels of the administration), but they also include contemporary newspapers (Diario de Barcelona, 1874), personal accounts (Salvadó, 1875) and local historians' research (Pleyán de Porta, 1945; Iglésies, 1971; Xuclà, 1977; Piqué, 1986; Coma, 1990; Vila, 1992; Espinagosa et al., 1996; Còts, 2012).

Besides this archive information, flood marks are also very important pieces of information in hydraulic modeling, because they precisely mark the maximum height of the water, which can be equated (with a small, acceptable error) to the height of the water at the peak of the flood.

Twelve flood marks were used in the hydraulic modeling of the ten recon- 
structed peak flows. Some of them are plaques whereas others are simple carv-

ings on the walls and even others are mere notes found in written documents (Table 2).

The reliability of these twelve flood marks is generally high, since most of them have been confirmed by local historians and experts. There is only a slight suspicion that the Agramunt mark might have been moved. This one scored 2 (moderately reliable) in the three-degreed classification of reliability by (Bayliss \& Reed, 2001), whereas the other marks all scored 3 (very reliable). The precision of a flood mark (that is, the maximum expected difference between the flood mark and the actual maximum water height) depends on its reliability and on its nature. Those flood marks with a high reliability and a physical nature (a plaque or an incision) were given a precision of $\pm 10 \mathrm{~cm}$. The one with moderate reliability (Agramunt) and the two of a written nature (Cervera and Vallfogona de Riucorb) were given a precision of $\pm 30 \mathrm{~cm}$ (Table 2).

\subsection{Hydraulic modeling}

The objective of the hydraulic modeling was the calculation of the peak flows at the ten sites. It was done from the maximum water heights observed (Table 2), because it was considered (accepting a minimum error) that these maximum heights occurred simultaneously with their corresponding peak flows.

The hydraulic model used was the one-dimensional HEC-RAS 4.0 (USACE, 2008) under gradually varied, steady, mixed flow. Actually, this model calculates water height from a flow value. Therefore, we applied it iteratively, trying tentative peak flows until the difference between the modeled water height and 
the actual flood mark was smaller than $1 \mathrm{~cm}$ (Figure 3).

The HEC-RAS model needs as input data:

1. the channel's geometry (cross sections shape and channel's longitudinal slope), given by the cross sections of the digital terrain model,

2. the Gauckler-Manning roughness coefficients (also known as Manning's n), that relate friction with type of surface and are found in tables (Chow et al., 1994),

3. the boundary and initial conditions, which tell what is happening upstream and downstream the modeled river reach,

4. the aforementioned tentative peak flow.

All these input data are limited to a river reach, usually less than $2 \mathrm{~km}$ long, upstream and downstream the flood mark site. However, the data had to be adequately adapted to be as close as possible to their values at the time when Santa Tecla floods took place. Old maps, engravings and written descriptions were used to reconstruct the channel and floodplain morphology at the time of the flood (obstacles such as human structures, meanders and islands, and cross sections' contractions or expansions) and to hypothesize the roughness coefficients. Table 3 lists the changes in each of the ten modeled sites.

Model calibrations, which help better estimate the input data, were not possible because none of the studied catchments has ever had flow gauges, except Francolí; but even in that case, no high enough flood records with an associated flood mark that could be modeled were available. However, in Tàrrega, the hydraulic model could be calibrated with the hydrologically modeled peak flow 
of a rainstorm occurred in 1989, of which there existed a measured hyetograph and a photograph marking the maximum water height. In any case, this is only an approximate calibration.

Besides, also in Tàrrega, the existence of three flood marks along the river reach, allowed to choose the correct river-bed morphology between two possible ones (Balasch et al., 2011).

In this same town, the previous reconstruction of six other historical floods allowed the calculation of Santa Tecla's peak flow return period (Balasch et al., 2011). In Montblanc, the peak flow return period was calculated from a series of measurements in the period 19462014 (Junta d'Aigües, 1995). is inevitably transferred to the results. In order to estimate this uncertainty, a sensitivity analysis of the hydraulic modeling was performed in 5 of the 10 sites.

More specifically, the effects of two input variables on the resulting peak flows were assessed: maximum water height and the Gauckler-Manning roughness coefficients (or Manning's n). This was done by estimating a value of uncertainty or error for those two variables: the precision values of the flood marks given in Table 2, for the maximum water height; and $\pm 30 \%$ for the Gauckler-Manning roughness coefficients (Marcus et al., 1992; Johnson, 1996; Wohl, 1998) and then separately calculating the relative error in the peak flow results that each one of these input errors would cause. The two resulting relative errors were then quadratically added as follows: 


$$
\delta_{Q, \text { total }}=\sqrt{\delta_{Q, \text { height }}^{2}+\delta_{Q, \text { Manning }}^{2}}
$$

where $\delta_{Q \text {,total }}$ is the peak flow total relative error, $\delta_{Q \text {, height }}$ is the peak flow relative error caused by the error in maximum water height, and $\delta_{Q, \text { Manning }}$ is the peak flow relative error caused by the error in Manning's n. Relative errors have no units and are given in parts-per-one. In two of the five sites, only the relative error caused by maximum water height was calculated.

\subsection{Hydrological modeling}

The objective of the hydrological reconstruction was the calculation of the hyetograph of the rain that caused the flood.

To this end, the hydrological modeling software HEC-HMS 3.3 (USACE, 2010) was used. HEC-HMS is an empirical, lumped rainfall-runoff model, which allows the user to choose among an array of different empirical methods for three hydrological processes: runoff generation, transformation of runoff into river flow, and river flow routing. For each of these processes we chose, respectively, the SCS Curve Number, the SCS Synthetic Unit Hydrograph and the Muskingum-Cunge methods, because of their simplicity of use, their moderate requirements in input data and their being generally accepted and commonly used (NRCS (Natural Resources Conservation Service), 2007).

Similarly as in the hydraulic reconstruction, the calculation procedure is iterative, because the result (that is, the hyetograph) is, actually, an input datum required by the model (Figure 4). Therefore, a tentative hyetograph 
must be built using the available historical information about the rain event, such as its duration and other indications that can lead to a rough estimation of the rainfall volume. Hence, only in those cases when all these required data 220 were available, the tentative hyetograph could be built and the hydrological modeling, performed; more specifically, this could be done in five sites: Montroig by the Sió River, Cervera and Tàrrega by the Ondara River, and Ciutadilla and Guimerà by the Corb River.

Besides this tentative hyetograph, the model needs input data describing the catchment (and subcatchments) hydrological characteristics, such as soil type (and its hydrological characteristics), land use and cover, antecedent soil moisture condition, and the main stream's length, slope, and Gauckler-Manning roughness coefficient.

These data had to be adapted, when necessary, from present-day values to the estimated ones at the time of the studied flood. Particularly, the antecedent soil moisture condition was estimated from the historiographical research ${ }^{1}$ and confirmed with the meteorological analysis; condition III (saturated soils) was ultimately chosen. According to SCS Curve Number model, for condition III to be chosen, it must have rained at least $53 \mathrm{~mm}$ in the five previous days. Regarding soil uses and cover, none of the three modeled catchments suffered major changes since 1874. They all are mostly rural, with non-irrigated cereal crops and small patches of Mediterranean forest.

\footnotetext{
${ }^{1}$ For example, Pleyán de Porta (1945) states that the soils in the Sió, Ondara and Corb catchments were at field capacity due to a generous rain on 18th September 1874, just five days before Santa Tecla rainstorm.
} 
The result of the hydrological modeling (the peak flow) was then compared to the one calculated in the hydraulic modeling; if the two were similar enough (less than $1 \%$ apart), the tentative hyetograph was accepted. Then, the approximate return period of the total rainfall was estimated from maps drawn by Casas (2005).

As happened in the hydraulic modeling, calibrations of the hydrological models in the five modeled sites were not possible because none of the studied catchments has ever been gauged. However, as said in Section 3.2., an event occurred in 1989 allowed to calibrate both the hydraulic and the hydrological models in the town of Tàrrega in the Ondara catchment.

However, in order to estimate the real amount of uncertainty in the results, a sensitivity analysis was done by observing the variation in the results caused by variations in the input variables: the influence of Curve Number and Synthetic Unit Hydrograph's lag time on peak flow (which is the actual output of the model), and the influence of antecedent soil moisture condition on total rainfall (which is, as part of the hyetograph, our aimed result). This was done in two of the five sites: Mont-roig and Tàrrega. value is estimated with tables from soil type, land use and land cover (NRCS, 2007) and it is therefore somewhat arbitrary. Thus, we assumed an error of \pm 10 units in its estimation, slightly more conservative than the $\pm 10 \%$ value suggested by Hawkins (1975). 
method treats this parameter as a qualitative discrete variable called antecedent soil moisture condition, with three possible values: dry (I), intermediate (II), and saturated (III). In practice, a change in antecedent soil moisture condition entails a change in the Curve Number value. In this way, we assessed the influence in total rainfall of a change in antecedent soil moisture condition from III (saturated) to II (intermediate), which equates to a reduction in the Curve Number of around 8 units. However, an error in this parameter seems quite unlikely, given the written accounts that describe a rainy week before the floods (Diario de Barcelona, 1874; Pleyán de Porta, 1945). half of the rain has fallen and the moment of the peak flow. Lag time is indirectly calculated with an empirical equation that only requires the main stream's length and slope (NRCS (Natural Resources Conservation Service), 2007):

$$
t_{\text {lag }}=0.6 \cdot 0.66 \cdot\left(\frac{L}{J^{0.5}}\right)^{0.77}
$$

where $t_{\text {lag }}$ is the lag time (in hours), $L$ is the length of the main stream (in km) and $J$ is the mean slope of the main stream (in parts-per-one).

This indirect way of calculating lag time results in a high uncertainty. Indeed, Bell \& Om Kar (1969) state that lag time may vary from about $70 \%$ to $140 \%$ of the value found with Eq. (2); besides, they also conclude that lag time for extreme floods is $10 \%$ shorter. Thus, we decided to assess the influence of a ${ }_{280} \pm 40 \%$ error in lag time on peak flow.

As in the hydraulic modeling (see Eq. 1), total relative error in peak flow was 
calculated quadratically summing the relative errors caused by Curve Number and by lag time.

\subsection{Meteorological analysis}

The objective of the meteorological analysis was to determine the meteorological processes that caused the flood. More precisely:

a) To describe the synoptic conditions (atmospheric situation at several levels) during 1874 Santa Tecla floods. This meteorological analysis allowed, on the one hand, to determine the cause of the floods and, on the other hand, to validate the hyetograph found in the hydrological modeling. If the former could be done with many floods in the region, flood forecasting would be improved.

b) To assess the possibility of rainfall in the weeks before the floods in order to estimate the antecedent soil moisture condition, a piece of information needed in the hydrological modeling.

This analysis was performed by using the National Oceanic and Atmospheric Administration (NOAA) 20 ${ }^{\text {th }}$ Century Reanalysis, available from 1 January 1871 onwards (Compo et al., 2011). This was done by directly analyzing the maps and also by calculating several indexes that measure the convection intensity:

a) the Convective Available Potential Energy (CAPE, Mapes (1993); Doswell III \& Rasmussen (1994)) 
b) the Lifted Index LI (Galway, 1956).

c) the K-index (George, 1960).

305

d) Vertical, Cross and Total Totals indexes (Miller, 1972).

e) the Humidity index (Litynska et al., 1976).

f) the difference between the lifted condensation level (LCL) and the level of free convection (LFC)

g) the limit of convection (LOC).

h) the wind shear between surface and $1 \mathrm{~km}$, between surface and $3 \mathrm{~km}$.

These convectivity indexes were calculated approximately over the town of Valls $^{2}$, located within the Francolí River catchment (Figure 1).

Additionally, three pressure indexes, which measure the difference in surface pressure between two distant locations, were also calculated for every day of the month of September 1874 from contemporary daily measurements:

a) The WeMo index, between Cádiz and Padua (Martín-Vide \& López-Bustins, 2006).

b) The NOA index, between Cádiz and Reykjavík.

c) A zonal index between Cádiz and Uppsala.

\footnotetext{
${ }^{2}$ UTM coordinates of Valls: $X=335500 \mathrm{~m} ; Y=4572000 \mathrm{~m} ; Z=200 \mathrm{~m} ; \mathrm{UTM} 31 \mathrm{~T} /$
} ETRS89 


\section{Results and discussion}

The results of the reconstruction of 1874 Santa Tecla flood and their discussion are presented in several sections corresponding to the different phases of the reconstruction.

\subsection{Historiographical research}

325

330 sion crossed Catalonia between 17 and 19 September; there are records of rainfall in Zaragoza on 17 and 18 September, Valencia on $18(28.6 \mathrm{~mm})$ and Barcelona on $19(30 \mathrm{~mm})$. This episode of rain left the soil very wet (Pleyán de Porta, 1945 ) and, thus, with a reduced ability to absorb the precipitation that would fall on the day of Santa Tecla.

Indeed, after a few days of calm, the night of 22 to 23 September 1874, a strong thunderstorm driven by SE, SSE and S strong winds affected the coast and the southern half of Catalonia; these precipitations caused floods in many small catchments throughout an area of around $10000 \mathrm{~km}^{2}$ (Diario de Barcelona, 340 1874) (Figs. 1 and 5). In Barcelona, from the only rainfall measurement found, it rained $63 \mathrm{~mm}$ on 23 September, almost the average precipitation of the whole 
month.

As an example of the quickness of the events, Iglésies (1971) reports that, in Tàrrega (in the Ondara catchment), the rain, which had started at 09:00 345 p.m. LT (local time, UTC) on 22 September, grew more intense at around 01:00 a.m. LT and lasted two more hours, and that the peak flow of the flood occurred between 03:00 and 03:30 a.m. LT. Almost the same happened in the Francolí River: the downpour began at 01:00 a.m. LT, and the peak flow reached Tarragona (the outfall of the catchment) at around 03:00 a.m. LT (Diario de Barcelona, 1874; Iglésies, 1971).

The historiographical sources and the contemporary newspapers consulted (Diario de Barcelona, 1874; Iglésies, 1971; Coma, 1990; Barriendos \& Pomés, 1993; Espinagosa et al., 1996; Còts, 2012) list fisty-one locations where the rain caused floods, thirty-one of them destructive (see Fig. 5). storm. Indeed, most of the thirty-one destructive floods cluster along the rivers with headwaters on either side of the southern Pre-coastal ranges; that is, along both the leeward ones (like Sió, Ondara, Corb and Vall Major) and the windward ones (like Francolí and Gaià) (Figure 1). Therefore, these windward rivers acted as natural corridors for the southeastern wind, which pushed the stormy air mass up to the top of the Pre-coastal ranges, where it developed and precipitated. This explanation agrees with the meteorological analysis (section 4.4) and with the rainfall distribution, with higher rainfalls in the catchments' headwaters (section 4.3). 
Outside this most severely affected area in the southern half of Catalonia, there were two non-destructive overbank floods along the northeastern coast, which point out that the turbulent activity also affected that area. In contrast, rainfall was scarce on the northern half of inland Catalonia.

\subsubsection{Damages}

Santa Tecla floods were catastrophic both in terms of both affected area (about $10000 \mathrm{~km}^{2}$ ) and degree of destruction. Since the rainstorm began past midnight and affected small, quick-response catchments -with lag-times of $4 \mathrm{~h}$ or less- the damages along the rivers were huge: about 700 collapsed dwellings, and destroyed crops and infrastructures. In total, 960 structural elements were damaged, 643 of which were completely destroyed or suffered irreparable damage. The most affected county, Urgell, where 452 elements were completely destroyed (Figure 6 and Table 4), is crossed by the Siò, Ondara and Corb Rivers.

Actually, Santa Tecla floods destruction is comparable to that of the floods occurred in 1617, known as "The Year of the Deluge" which destroyed 389 buildings, 22 bridges and 17 mills in Catalonia (Thorndycraft et al., 2006).

The cost of the damages of Santa Tecla in only one of the two most damaged provinces has been estimated to be at least 100 million Euros (updated to the year 2014 values) (Lladonosa, 1974).

385 Besides destroyed buildings and general structures, damages in agriculture were great and varied: loss of fertile soil and fruit trees, destruction of irrigation structures and mills, and loss of seed, seedlings, and staples (grain, beans, nuts, 
olive oil, and wine) stored in destroyed warehouses. The economic impact of such damage is difficult to assess, but it was enormous: agriculture was the basis of the economy of the region at the time, and recovering required many years. The floods caused thus a long-lasting impoverishment of the population. In addition to this, the reconstruction tasks were hampered by the Third Carlist War (1872-1876).

\subsubsection{Casualties}

Adding up the figures found in the historiographical sources and contemporary press, 575 people died because of the floods (Diario de Barcelona, 1874; Iglésies, 1971). The distribution of victims (Figure 7), is almost identical to that of damages, with again the most affected county being Urgell, traversed by the Sió, Ondara and Corb rivers. In this county alone, 293 people died, 205 of them in its capital town Tàrrega.

The sudden nature of these flash floods and the fact that they occurred past midnight are the main reasons for this large number of fatalities.

Santa Tecla floods caused more deaths than the floods occurred in Catalonia in 1907 (29 deaths), 1940 (90 deaths), but less than the highly destructive floods of 1962 (more than 815 deaths).

\subsection{Hydraulic modeling}

The results of the hydraulic modeling are shown in Table 5. In four of the ten sites (Cervera, Vallfogona de Riucorb, Espluga de Francolí and Montblanc), the specific peak flow is extremely high $\left(\geq 9.6 \mathrm{~m}^{3} \mathrm{~s}^{-1} \mathrm{~km}^{-2}\right)$. However, they 
$\mathrm{km}^{-2}$ ) of a recent inventory of extreme floods in France from 1770 to 2011 (Lang \& Coeur, 2014), and rank among the highest values of the flash floods collected by Gaume et al. (2009) in similar-sized catchments (between 50 and $350 \mathrm{~km}^{2}$ ) in the Western Mediterranean area.

415 Francolí River in Montblanc, is 5.5 (Table 5), and it is, therefore, higher than the $\mathrm{K}$ indexes of the highest measured and reconstructed flows of severe flash floods in Mediterranean catchments of the Iberian Peninsula and southern France (Figure 8). The K index, calculated with Eq. (3), is used to compare peak flows 420 2003).

$$
K=10\left(1-\frac{6-\log _{10}(Q)}{8-\log _{10}(A)}\right)
$$

where $K$ is the adimensional $K$ index, $A$ is the area in $\mathrm{km}^{2}$, and $Q$ is the flow in $\mathrm{m}^{3} \mathrm{~s}^{-1}$.

The exceptionality of these values is furthermore confirmed by the observed return period of the peak flows in Tàrrega and Montblanc: around 260 years. This return period was calculated, in the case of Tàrrega, with the series of reconstructed flows of historical floods shown in Table 6 and, in the case of Montblanc, with a series of measured peak flows for the period 1946-2014 (Junta d'Aigües, 1995). 
vided by the mean flow) are between 500 and 5500 in the ten catchments; these values are not extraordinary if compared to the maximum ones (between 5000 and 10000) calculated by Conacher \& Sala (1945) for Mediterranean torrents of the Iberian Peninsula. However, our torrentiality indexes may be underestimated since some of the mean flows from which they have been calculated might be overestimated due to the seepage of irrigation water.

Water velocities in the channels are very varied, with some very high values $\left(>7 \mathrm{~m} \mathrm{~s}^{-1}\right)$ that explain the magnitude of the damages and casualties.

The relative errors of the peak flows calculated in the sensitivity analysis are between $\pm 5 \%$ and $\pm 44 \%$ (Table 7 ). These error values for peak flow modeling are far better than 50\%, the highest value deemed as acceptable in historical floods reconstruction (Barriendos et al., 2003) and, if the two calculated from the least precise flood marks are excluded, they are close to those typical in flow measurement, which should be more precise than flow modeling: $\pm 6-19 \%$ ${ }_{445}$ (Harmel et al., 2006b) and $\pm 10 \%$ (Butts et al., 2004).

It must be noted, however, that our values are lower bounds for peak flow error, since they were calculated from water height and roughness coefficients errors and, therefore, the error caused by the rest of the input data (such as channel's shape and slope, or boundary and initial conditions) have not been taken into account yet. However, the objective of this simple sensitivity analysis was to obtain an estimation of the order of magnitude of the error. Other reconstruction studies base their sensitivity analyses on the same variables and obtain similar results (Barriendos et al., 2003; Neppel et al., 2010; Herget et al., 
2014).

The peak flow relative error caused by the uncertainty in maximum water height goes from $\pm 3 \%$ to $\pm 13 \%$ when flood mark precision is $\pm 10 \mathrm{~cm}$ and from $\pm 17 \%$ to $\pm 44 \%$ when flood mark precision is $\pm 30 \mathrm{~cm}$. These differences are most probably due to the cross sections' shape: in wider sections, a small increase in water height means a greater increase in water flow than in narrower sections.

Similarly, one of the peak flow relative errors caused by the uncertainty in Manning's $n$ is also smaller than the rest, that of Tàrrega. This may be caused, again, by differences in the geometry of the reach: reaches with high slopes and high hydraulic radius are less influenced by changes in Manning's $n$ than reaches with the opposite features.

\subsection{Hydrological modeling}

The results of the hydrological modeling are shown in Tables 8 and 9 and in Figure 9. Total rainfall values must be deemed quite exceptional, judging from their approximate return periods, which were estimated from regional maps drawn by Casas (2005). Besides, maximum rainfall intensity values qualify as torrential, according to a classification by the Spanish Meteorological Institute (Llasat, 2001).

Similarly, the values of the ratio 'Storm rainfall / mean annual rainfall' were greater than those found for flash-flood-causing rainstorms of the same duration (about 6 h) by Marchi et al. (2010), which are all below 0.2 .

IIn the four catchments with more than one studied site, specific peak flows decrease downstream, between 20 and $60 \%$ (Table 5); this could mean that 
rainfall was heavier in the catchments' headwaters, which is consistent with the conclusions drawn from the historiographical research and the meteorological analysis.

The runoff coefficients are very high, especially in the Ondara catchment, and are higher than the highest but one runoff coefficients of flash flood-causing rainstorms of the same magnitude (between 110 and $150 \mathrm{~mm}$ ) in the Mediterranean region calculated by Marchi et al. (2010). These high runoff coefficients are a consequence of the selection of the antecedent soil moisture condition III (saturated soils caused, according to the model, by at least $53 \mathrm{~mm}$ of rain in the five previous days). This soil moisture condition was selected to agree with the accounts of the event (Diario de Barcelona, 1874; Salvadó, 1875; Pleyán de Porta, 1945). Soil saturation translated in an increased impermeability of the catchments and contributed to the magnitude of the floods.

Lag times range between 2.5 and $4 \mathrm{~h}$, which agree with the torrential nature of these streams and the suddenness of the floods; they also agree with the values found by Marchi et al. (2010) in flash-flood-causing rainstorms in similar-sized catchments (between 50 and $350 \mathrm{~km}^{2}$ ) in the Mediterranean region.

The sensitivity analysis shows that the hydrological modeling results are quite sensitive to changes in input data. Indeed, relative errors in peak flow caused by errors in two input data (Curve Number and lag time) calculated in two of the sites are around $\pm 36 \%$ (Table 10); the Curve Number alone causes an error in peak flow of $\pm 23 \%$ to $\pm 28 \%$ and the lag time alone, an error of $\pm 23 \%$ to $\pm 27 \%$. This agrees with the findings of Ponce \& Hawkins (2001) for Curve 
Number influence on results.

The effect of these variables in total rainfall error is yet to be calculated, but it is probably of the same order of magnitude. Indeed, the error in total rainfall caused by an error in antecedent soil moisture condition (or by the equivalent decrease of 8 units in the Curve Number value) is $+30 \%$. Therefore, hydrological modeling results should be seen as merely approximate.

\subsection{Meteorological reconstruction}

According to the maps from NOAA's 20th Century Reanalysis (Compo et al., 2011) shown in Figure 10, on 23 September 1874, a very stable and deep depression located in the center of the Iberian Peninsula had been blowing southerly winds onto Catalonia for at least 10 days. These winds brought warm, moist air that accumulated in the low levels of the troposphere due to the presence over Catalonia of an African ridge (a mass of hot air) at mid-levels (at a height between $850 \mathrm{hPa}$ and $500 \mathrm{hPa}$ or, approximately, between $1500 \mathrm{~m}$ and 5500 m), which prevented vertical movements. Indeed, those warm and moist winds hadn't been able to move to upper levels until 23 September, when the African ridge withdrew. Only then, the warm, moist air mass could rapidly rise forming thick clouds and, eventually, thunderstorms; this rise was furthermore enhanced by the presence of the Pre-coastal mountain ranges, which run parallel to the coast about $30 \mathrm{~km}$ inland.

This succession of events, which we have named flash triggering effect (Mazon et al., 2014), is the same process that caused the equally destructive 1962 floods in a 
nearby area (Vallès) (Ruiz-Bellet et al., 2013). Due to its suddenness, this process is very difficult to forecast (Maddox et al., 1979).

This interpretation of the synoptic maps is backed by the convectivity in525 dexes calculated from the same NOAA's 20th Century Reanalysis data. Indeed, all these indexes but one (wind shear $1 \mathrm{~km}$ ) have values related to severe thunderstorm weather around the time of the storm, that is, 23 September 1874 at midnight (Table 11). These values are also extreme when compared to the values of the other fourteen heaviest floods in Catalonia since 1871; indeed, Santa Tecla indexes are always in the top three (Mazon et al., 2014).

Besides, the three pressure indexes (WeMo, NAO, and Cádiz-Uppsala) show a sharp drop-off between 18 and 22 September at noon, especially NAO and Cádiz-Uppsala (Fig. 11). This means that an area of low pressure located over the Iberian Peninsula grew deeper over that period, with a minimum between 22 and 23 September, thus creating a great vertical instability.

In conclusion, three different methods (synoptic maps, convectivity indexes, and pressure indexes) agree with the possibility of an extraordinary thunderstorm having the high rainfall values calculated in the hydrological modeling and the destructive effects described by the historical sources.

On the other hand, the synoptic conditions for 18 September 1874, five days before the floods (Figure 12), also agree with the possibility of an abundant rain that saturated the soils, as described by Pleyán de Porta (1945), which led to the selection of an antecedent soil moisture condition of III (saturated soils caused, according to the model, by at least $53 \mathrm{~mm}$ of rain in the five previous 
days) in the hydrological modeling.

\subsection{General discussion}

This study is one of the first examples of a complete reconstruction of a flash flood from historical information: historiographical, hydraulic, hydrological and meteorological. Indeed: although historical floods reconstructions

550 have increased in number in the last two decades, especially due to EU Directive 2007/60/EC (2007) on flood risk assessment, most of these limit to hydraulic modeling and only a few attempt some sort of hydrometeorological reconstruction (Benito et al., 2003; Delrieu et al., 2005; Bürger et al., 2006; Ducrocq et al., 2008; Milln, 2008).

This study is also innovative in that it reconstructs the floods in ten different sites located in five catchments in order to have an idea of the spatial distribution of the event.

1874 Santa Tecla floods, which previously was a somewhat unknown and ignored record in regional historical flood compilations (Llasat et al., 2005; Barriendos \& Rodrigo, 2006), reveals as a first order hydrological and meteorological event, with both great peak flows and destruction, which affected an area of $10000 \mathrm{~km}^{2}$.

\section{Conclusions}

The innovative interdisciplinary methodology used allowed us to achieve, from the historical information available, a complete reconstruction and, thus, 565 a thorough understanding of 1874 Santa Tecla floods. 
These floods seem to be exceptional according to the results of the hydraulic and hydrological modeling and were indeed exceptional in terms of destruction. This exceptionality is confirmed by two peak flows return period (around 260 years) and the total rainfall approximate return periods (between 250 and more than 500 years). However, it must be noted that, accepting a 250 year return period, the probability of having an event of the same magnitude at least once in the next 50 years is $18 \%$ and in the next 100 years, $33 \%$. Besides, floodplain occupation, and, thus, exposition to floods, has increased greatly since 1874; therefore, damages of Santa Tecla floods could be much greater nowadays. impermeability of the catchment caused by soil saturation due to rainfalls in the five previous days than of the magnitude of the rain the day of the floods.

The information generated can be used to calculate return periods in the ungauged catchments where the floods occurred and to improve the forecast of these kinds of events. Indeed, since the synoptic situation and the ensuing meteorological processes that caused these floods have been determined, alert protocols could be prepared to early warn civil protection services in the occurrence of similar synoptic and hydrological circumstances. All this should translate in a limited number of victims if Santa Tecla floods occurred again.

The peak flow estimation obtained in the hydraulic modeling was quite accurate. In contrast, the uncertainty of the hydrological modeling results was somewhat higher. Nevertheless, these results are still useful if taken as approximations. However, in both cases, the error values found were only lower bound 
estimations and further research must be done to improve error calculation with other sources of error (other input data) and in different types of catchment.

\section{Acknowledgments}

Known and unknown people of the past recorded and preserved valuable information of the floods that made this study possible.

Xavier Castelltort (CSIC), Ferran Riba, Adrià Marquilles and Roger Sosa (UdL) informed of three flood marks. Álvaro Tena and Damià Vericat (RIUSUdL) and Carlos Astudillo (UdL) helped in the topographic survey of the flood marks. Topographic survey equipment was provided by RIUS-UdL Fluvial Dynamics Research Group. Joaquín Martín de Oliva, Sandra Guerrero and Albert Garcia (UdL) calculated four of the ten peak flows. Oriol Saula (Tàrrega County Museum) provided useful archaeological and historical information. José Antonio Martínez-Casasnovas drew the maps in Figure 1. Ramon J. Batalla (RIUS-UdL) and Quim Farguell (ACA) helped complete 1946-2014 peak flow series of Francolí River in Montblanc.

20th Century Reanalysis V2 data provided by the NOAA/OAR/ESRL PSD, Boulder, Colorado, USA, from their Web site at http://www.esrl.noaa.gov/psd/. Support for the Twentieth Century Reanalysis Project dataset is provided by the U.S. Department of Energy.

The editor Konstantine Georgakakos and two anonymous reviewers made suggestions that improved the text.

The authors were financed by Spanish MINECO projects CGL2012-35071 
and CGL2012-37416-C04-03, and by the INTERREG EU project FLUXPYR EFA 34/08. One of the authors has a pre-doctoral grant from the University of Lleida.

\section{References}

Balasch, J. C., Ruiz-Bellet, J. L., \& Tuset, J. (2011). Historical flash floods retromodelling in the Ondara River in Tàrrega (NE Iberian Peninsula). Nat. Hazard. Earth Sys. Sci., 11, 3359-3371.

Balasch, J. C., Ruiz-Bellet, J. L., Tuset, J., \& Martín de Oliva, J. (2010a). Reconstruction of the 1874 Santa Tecla's rainstorm in Western Catalonia (NE Spain) from flood marks and historical accounts. Nat. Hazard. Earth Sys. Sci., 10, 2317-2325.

Balasch, J. C., Tuset, J., \& Ruiz-Bellet, J. L. (2010b). Reconstructing the 1874 Santa Tecla flash flood in the Ondara River (Ebro Basin, NE Spain). Adv. Geosci., 26, 45-48.

Barrera, A., \& Cunillera, J. (2011). Primer informe sobre la generació d'escenaris climàtics regionalitzats per a Catalunya durant el segle XXI. Technical Report Servei Meteorològic de Catalunya, Departament de Territori i Sostenibilitat, Generalitat de Catalunya.

Barriendos, M., Coeur, D., Lang, M., C., L. M., Naulet, R., Lemaitre, F., \& Barrera, A. (2003). Stationarity analysis of historical flood series in France and Spain (14th-20th centuries). Nat. Hazards Earth Syst. Sci., 3, 583-592. 
Barriendos, M., \& Pomés, J. (1993). L'aigua a Mataró: Inundacions i recursos hídrics (ss. XVIII-XX). Mataró (Spain): Caixa d'Estalvis Laietana.

Barriendos, M., \& Rodrigo, F. (2006). Study of historical flood events on Spanish rivers using documentary data. Hydrol. Sci. J., 51, 765-783.

Barriendos, M., Ruiz-Bellet, J. L., Tuset, J., Mazon, J., Balasch, J. C., Pino, D., \& Ayala, J. L. (2014). The "Prediflood" database of historical floods in Catalonia (NE Iberian Peninsula) AD 1035-2013, and its potential applications in flood analysis. Hydrol. Earth Syst. Sci., 18, 4807-4823.

Barriendos, M., Tuset, J., Mazon, J., Pino, D., Ruiz-Bellet, J. L., \& Balasch, J. C. (2013). La rubinada de Santa Tecla a Tàrrega (23 de setembre de 1874). URTX Revista d'humanitats de l'Urgell, 27, 10-25.

Bayliss, A. C., \& Reed, D. W. (2001). The use of historical data in flood frequency estimation. Technical Report Report to MAFF. Centre for Ecology and Hydrology, NERC, Wallingford, UK.

Bell, F. C., \& Om Kar, S. (1969). Characteristic response times in design flood estimation. J. Hydrol., 8, 173-196. doi:10.1016/0022-1694(69) 90120-6.

Benito, G., Díez-Herrero, A., \& Fernández de Villalta, M. (2003). Magnitude and frequency of flooding in the Tagus basin (Central Spain) over the last ${ }_{650}$ millennium. Climatic Change, 58, 171-192.

Benito, G., Lang, M., Barriendos, M., Llasat, M. C., Francés, F., Ouarda, T., Thorndycraft, V. R., Enzel, Y., Bardossy, A., Coeur, D., \& Bobée, B. (2004). 
Use of systematic, palaeoflood and historical data for the improvement of flood risk estimation. review of scientific methods. Nat. Hazards, 31, 623-643.

Brázdil, R., Kundzewicz, Z. W., \& Benito, G. (2006). Historical hydrology for studying flood risk in Europe. Hydrolog. Sci. J., 51, 739-4764.

Bürger, K., Dostal, P., Seidel, J., Imbery, F., Barriendos, M., Mayer, H., \& Glaser, R. (2006). Hydrometeorological reconstruction of the 1824 flood event in the Neckar River basin (southwest Germany). Hydrolog. Sci. J., 51, 864877.

Butts, M. B., Payne, J. T., Kristensen, M., \& Madsen, H. (2004). An evaluation of the impact of model structure on hydrological modelling uncertainty for streamflow simulation. J. Hydrol., 298, 242-266.

Casas, M. C. (2005). Análisis espacial y temporal de las lluvias extremas en Catalunya. Modelización y clasificación objetiva. Ph.D. thesis University of Barcelona.

CHE (Confederación Hidrográfica del Ebro) (1996). Propuesta de Plan Hidrológico de la Cuenca del Ebro. Anexo 2: Aportaciones de las estaciones de aforo. Technical Report Ministerio de Medio Ambiente, Medio Rural y Marino, Madrid.

Chow, V. T., Maidment, D. R., \& Mays, L. W. (1994). Hidrología Aplicada. Bogotá (Colombia): McGraw Hill. 
Coma, M. T. (1990). Les inundacions en el terme municipal de Tàrrega. URTX. Revista Cultural de l'Urgell, 2, 249-260.

Compo, G. P., Whitaker, J. S., Sardeshmukh, P. D., Matsui, N., Allan, R. J., Yin, X., Gleason, B. E., Vose, R. S., Rutledge, G., Bessemoulin, P., Brnnimann, S., Brunet, M., Crouthamel, R. I., Grant, A. N., Groisman, P. Y., Jones, P. D., Kruk, M., Kruger, A. C., Marshall, G. J., Maugeri, M., Mok, H. Y., Nordli, Ross, T. F., Trigo, R. M., Wang, X. L., Woodruff, S. D., \& Worley, S. J. (2011). The Twentieth Century Reanalysis Project. Q. J. Roy. Meteor. Soc., 137, 1-28. doi:10.1002/qj.776.

Conacher, A., \& Sala, M. (1945). Land degradation in Mediterranean environment of the World: nature and extent. Chichester, New York: Wiley.

Corbella, D. (2003). Vallfogona de Riucorb. Imatge i memòria. Sant Vicent del Castellet: Farrell editors.

Corominas, J. (1985). L'acció catastròfica de les avingudes. In Història Natural dels Països Catalans. Recursos Geològics i Sòl (pp. 253-267). Barcelona (Spain): Fundació Enciclòpedia Catalana.

Còts, P. (2012). El pont baixmedieval sobre el riu Ondara de Tàrrega. Resultats de l'actuació arqueològica duta a terme l'any 2007. URTX. Revista Cultural de l'Urgell, 26, 116-131.

Delrieu, G., Ducrocq, V., Gaume, E., Nicol, J., Payrastre, O., Yates, E., Kirstetter, P.-E., Andrieu, H., Ayral, P.-A., Bouvier, C., Creutin, J.-D., Livet, 
M., Anquetin, S., Lang, M., Neppel, L., Obled, C., Parent-du Châtelet, J.,

Saulnier, G.-M., Walpersdorf, A., \& Wobrock, W. (2005). The catastrophic flash-flood event of 8-9 September 2002 in the Gard region, France: a first case study for the Cévennes-Vivarais Mediterranean Hydrometeorological Observatory. J. Hydrometeorol, 6, 34-52.

Diario de Barcelona (1874). 22 September-3 October 1874. Nrs. 258-269, pp. 9121-9568.

Doswell III, C. A., \& Rasmussen, E. N. (1994). The effect of neglecting the virtual temperature correction on CAPE calculations. Weather Forecast., 9, 625-629.

Ducrocq, V., Nuisier, O., Ricard, D., Lebeaupin, C., \& T., T. (2008). A numerical study of three catastrophic precipitating events over southern France. II: Mesoscale triggering and stationarity factors. Q. J. Roy. Meteor. Soc., 134, $131-145$.

Elleder, L. (2010). Reconstruction of the 1784 flood hydrograph for the Vltava River in Prague, Czech Republic. Global Planet. Change, 70, 117-124.

Espinagosa, J., Gonzalvo, G., \& Coma, T. (1996). La rubinada de Santa Tecla de 1874 a Tàrrega. Tàrrega: Ajuntament de Tàrrega.

EU Directive 2007/60/EC $(2007) . \quad$ On the assess-
ment and management of flood risks.
http://eur-lex.europa.eu/legal-content/EN/TXT/PDF/?uri=CELEX : $32007 \mathrm{~L} 006 \%$ O \& from=EN.


Flesch, T. K., \& Reuter, G. W. (2012). WRF model simulation of two Alberta flooding events and the impact of topography. J. Hydrometeorol., 13, 695708.

Francou, J., \& Rodier, J. (1967). Essai de classification des crues maximales observées dans le monde. In Cahiers ORSTOM, Série Hydrologie IV(3) (pp. $19-46)$.

Galway, J. G. (1956). The lifted index as a predictor of latent instability. $B$. Am. Meteorol. Soc., 37, 528-529.

Gaume, E., Bain, V., Bernardara, P., Newinger, O., Barbuc, M., Bateman, A., Blaskovicova, L., Blöschl, G., Borga, M., Dumitrescu, A., Daliakopoulos, I., García, J., Irimescu, A., Kohnova, S., Koutroulis, A., Marchi, L., Matreata, S., Medina, V., Preciso, E., Sempere-Torres, D., Stancalie, G., Szolgay, J., Tsanis, I., Velasco, D., \& Viglione, A. (2009). A compilation of data on European flash floods. J. Hydrol., 367, 70-78.

Gaume, E., Livet, M., Desbordes, M., \& Villeneuve, J. P. (2004). Hydrological 730 analysis of the river Aude, France, flash flood on 12 and 13 November 1999. J. Hydrol., 286, 135-154.

George, J. J. (1960). Weather Forecasting for Aeronautics. Academic Press.

Grieser, J. (2012). Convection parameters. URL: http://www . juergen-grieser.de/CovectionParameters/ConvectionParameters.pdf.

735 Harmel, R. D., Cooper, R. J., Slade, R. M., Haney, R. L., \& Arnold, J. G. 
(2006b). Cumulative uncertainty in measured streamflow and water quality data for small watersheds. T. Am. Soc. Agric. Biol. Eng., 49, 689-701.

Hawkins, R. H. (1975). The importance of Curve Numbers in the estimation of storm runoff. Water Resour. Bull., 11, 887-891. of historical floods. Hydrol. Earth Syst. Sci. Discuss., 11, 5463-5485.

Herschy, R. (2003). World Catalogue of Maximum Observed Floods. Publ. no. 284. Wallingford (UK): IAHS.

Iglésies, J. (1971). L'aiguat de Santa Tecla (23 de setembre del 1874). Barcelona (Spain): Rafael Dalmau.

Johnson, P. A. (1996). Uncertainty of hydraulic parameters. J. Hydraul. Eng.ASCE, 122, 112-114.

Junta d'Aigües (1995). Anuari de dades hidrològiques. Technical Report Generalitat de Catalunya Barcelona.

Lang, M., \& Coeur, D. (2014). Les inondations remarquables en France. Inventaire 2011 pour la directive Inondation. Quae.

Litynska, Z., Parniewicz, J., \& Pinkowski, H. (1976). The prediction of air mass thunderstorms and hails. Technical Report 200(R) World Meteorological Organization. Lleida (Spain): Artis Estudios Gráficos. 
Llasat, M. C. (2001). An objective classification of rainfall events on the basis of their convective features: application to rainfall intensity in the northeast of Spain. J. Climatol., 21, 1385-1400.

Llasat, M. C., Barriendos, M., Barrera, A., \& Rigo, T. (2005). Floods in Catalonia (NE Spain) since the 14th Century. Climatological and meteorological aspects from historical documentary sources and old instrumental records. $J$. Hydrol., 313, 32-47.

Llasat, M. C., Rigo, T., \& Barriendos, M. (2003). The Montserrat 2000 flash flood event: a comparison with the floods that have occurred in the northeastern Iberian Peninsula since the 14th century. J. Climatol., 23, 453-469.

López-Bustos, A. (1981). Tomando el pulso a las grandes crecidas de los ríos peninsulares. Revista de Obras Públicas, 3190, 179-192.

Maddox, R. A., Chappell, C. F., \& Hoxit, L. R. (1979). Synoptic and meso-alpha scale aspects of flash flood events1. B. Am. Metorol. Soc, 60, 115-123.

Mapes, B. E. (1993). Gregarious tropical convection. J. Atmos. Sci., 50, 20262037.

Marchi, L., Borga, M., Preciso, E., \& Gaume, E. (2010). Characterisation of selected extreme flash floods in Europe and implications for flood risk 775 management. J. Hydrol., 394, 118-133.

Marcus, W. A., Roberts, K., Harvey, L., \& Tackman, G. (1992). An evaluation 
of methods for estimating Manning's $\mathrm{n}$ in small mountain streams. Mt. Res. Dev., 13, 227-239.

Martín-Vide, J., \& López-Bustins, J. A. (2006). The Western Mediterranean Oscillation and rainfall in the Iberian Peninsula. J. Climatol., 26, 1455-1475.

Mazon, J., Balasch, J. C., Barriendos, M., Ruiz-Bellet, J. L., Tuset, J., \& Pino, D. (2014). Meteorological reconstruction of major floods in early instrumental period in Catalonia (NE Iberian Peninsula). In 14th EMS Annual Meeting. URL: http://presentations. copernicus .org/EMS2014-141_presentation.pdf.

Miller, R. C. (1972). Notes on analysis and severe storm forecasting procedures of the Air Force Global Weather Central. Technical Report 200(R) Air Weather Service, Scott Air Force Basem IL 62225.

Milln, M. M. (2008). Extreme hydrometeorological events and climate change predictions in Europe. J. Hydrol., 518, 206-234.

Naulet, R., Lang, M., Ouarda, T. B., Coeur, D., Bobée, B., Recking, A., \& Moussay, D. (2005). Flood frequency analysis on the Ardèche river using French documentary sources from the last two centuries. J. Hydrol., 313, 58-78.

Neppel, L., Renard, B., Lang, M., P-A., A., Coeur, D., Gaume, E., Jacob, N., Payrastre, O., Pobanz, K., \& Vinet, F. (2010). Flood frequency analysis using historical data: accounting for random and systematic errors. Hydrol. Sci. J., $55,192-208$. 
Nguyen, C. C., Gaume, E., \& Payrastre, O. (2014). Regional flood frequency analyses involving extraordinary flood events at ungauged sites: further developments and validations. J. Hydrol., 508, 385-396.

Ninyerola, M., Pons, X., \& Roure, J. M. (2005). Atlas Climático Digital de la Península Ibérica. Metodología y aplicaciones en bioclimatología y geobotánica. Bellaterra (Spain): Universitat Autònoma de Barcelona.

805 Novoa, M. (1987). Inundaciones en la cuenca del Pirineo Oriental. In L. Berga, \& J. Dolz (Eds.), Sistemas de previsión y alarma (pp. 375-397). Madrid (Spain): Colegio de Ingenieros de Caminos, Canales y Puertos.

NRCS (Natural Resources Conservation Service) (2007). National Engineering Handbook. Technical Report Natural Resources Conservation Center. US Department of Agriculture.

Pascual, R., Callado, A., \& Berenguer, M. (2004). Convective storm initiation in central Catalonia. In Proceedings of ERAD04 (pp. 464-468).

Petersen, W. A., Carey, L. D., Rutledge, S. A., Knievel, J. C., Doesken, N. J., Johnson, R. H., McKee, T. B., Haar, T. V., \& Weaver, J. F. (1999). Mesoscale and radar observations of the Fort Collins flash flood of 28 July 1997. B. Am. Meteorol. Soc., (pp. 191-216).

Piqué, J. J. (1986). Història i cultura de la vall del corb. In R. Boleda, J. Duch, D. Gelabert, \& J. Vallverdú (Eds.), La vall del riu Corb (pp. 78-136). Lleida (Spain): Institut d'Estudis Ilerdencs. 
Pleyán de Porta, J. (1945). Efemérides leridanas recogidas y ordenadas. Lleida

(Spain): Institut d'Estudis Ilerdencs. J. Sol and J. A. Tarragó (eds.).

Ponce, V. M., \& Hawkins, R. H. (2001). Runoff curve number: Has it reached maturity? J. Hydrol. Eng., 1, 11-19.

Romero, R., Ramis, C., \& Alonso, S. (1997). Numerical simulation of an extreme rainfall event in Catalonia: Role of orography and evaporation from the sea. Q. J. Roy. Meteor. Soc., 123, 537-559.

Ruiz-Bellet, J. L., Balasch, J. C., Tuset, J., Barriendos, M., Mazon, J., \& Pino, D. (2013). Meteorological analysis of 1874 Santa Tecla's flash floods in NE Iberian Peninsula. In EGU General Assembly 2013. URL: http://presentations. copernicus.org/EGU2013-11180_presentation.pdf.

Salvadó, J. (1875). Memoria de la inundación acaecida en la villa de Tárrega en la madrugada del día 23 de Setiembre de 1874, con una reseña históricocrítica de las que tuvieron lugar en la misma villa en 17 de Setiembre de 1644 , en 17 de Setiembre de 1783 y en 25 de Agosto de 1842. Barcelona (Spain): Establecimiento Tipográfico de Ramírez y Compañía.

Thorndycraft, V. R., Barriendos, M., Benito, G., Rico, M., \& Casas, A. (2006). The catastrophic floods of AD 1617 in Catalonia (northeast Spain) and their climatic context. Hydrolog. Sci. J., 51, 899-912.

USACE (2008). HEC-RAS River Analysis System: Hydraulic Reference Manual. Technical Report US Army Corps of Engineers, Hydrological Engineering Center, David, CA. 
USACE (2010). Hydrology Modeling System HEC-HMS Users Manual. Technical Report US Army Corps of Engineers, Hydrological Engineering Center, David, CA.

${ }_{845}$ Vila, J. (1992). Els canals d’Urgell $i$ la seva història. Lleida (Spain): Diputació de Lleida.

Wohl, E. E. (1998). Uncertainty in flood estimates associated with roughness coefficient. J. Hydraul. Eng.-ASCE, 124, 219-223.

Xuclà, R. M. (1977). Sopar al molí d'en Grau. Segarra, 773, 1-3. 
Table 1: Morphological and hydrographical characteristics of the ten catchments were the hydraulic and, in some cases, the hydrological reconstructions were performed. Own elaboration from various sources.

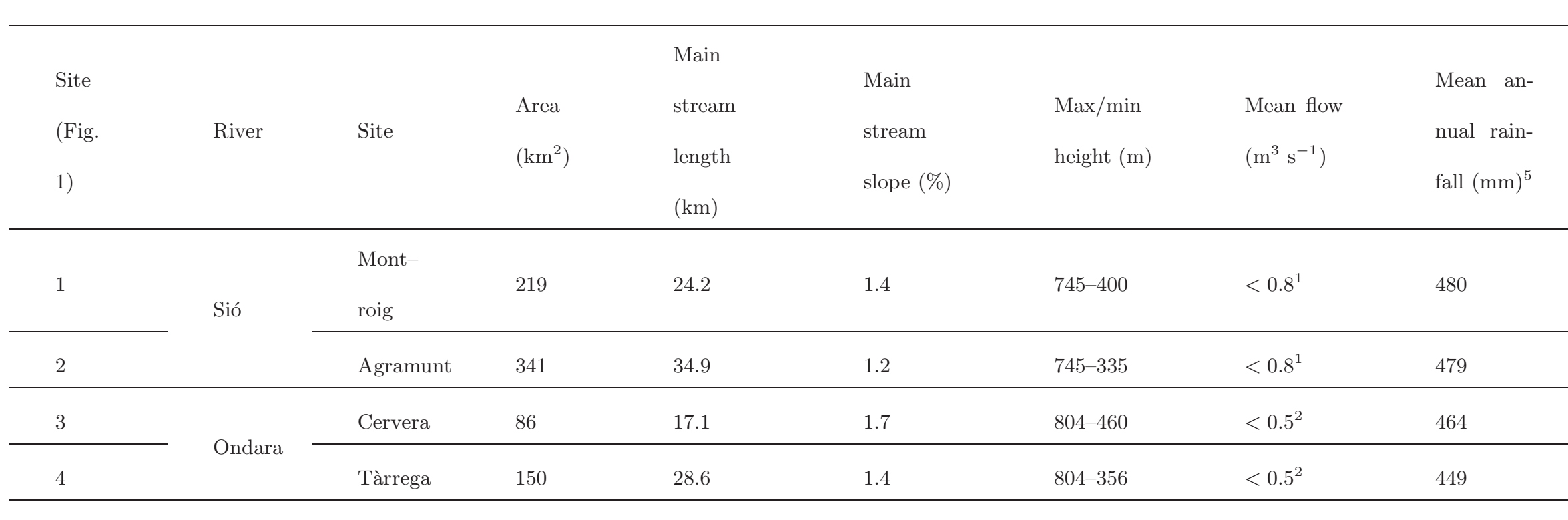




\begin{tabular}{|c|c|c|c|c|c|c|c|c|}
\hline \multirow{3}{*}{5} & \multirow{5}{*}{ Corb } & \multicolumn{7}{|l|}{ Vallfogona } \\
\hline & & de Ri- & 46 & 10.4 & 1.8 & $890-698$ & $<0.9^{3}$ & 509 \\
\hline & & \multicolumn{7}{|l|}{ ucorb } \\
\hline 6 & & Guimerà & 91 & 15.0 & 1.7 & $890-500$ & $<0.9^{3}$ & 418 \\
\hline \multirow[t]{3}{*}{7} & & Ciutadilla & 123 & 19.6 & 2.2 & $890-450$ & $<0.9^{3}$ & 459 \\
\hline & & \multicolumn{7}{|l|}{ Granyena } \\
\hline & Vall & de les & & & & & & \\
\hline \multirow[t]{3}{*}{8} & Ma- & & 50 & 17.0 & 2.1 & 670-309 & 0 & 410 \\
\hline & & Gar- & & & & & & \\
\hline & & rigues & & & & & & \\
\hline \multirow{4}{*}{9} & \multirow{5}{*}{ Francolí } & Espluga & & & & & & \\
\hline & & de & & & & & & \\
\hline & & Fran- & 101 & 16.3 & 3.9 & $1050-404$ & $0.3^{2}$ & 537 \\
\hline & & colí & & & & & & \\
\hline 10 & & Montblanc & 344 & 25.5 & 3.0 & $1050-284$ & $0.6^{4}$ & 528 \\
\hline
\end{tabular}


${ }^{1}$ Gauging station: Balaguer, EA182, period: 1965-1992

${ }^{2}$ CHE (Confederación Hidrográfica del Ebro) (1996)

${ }^{3}$ Gauging station: Vilanova de la Barca, EA183, period: 1965-1992

${ }^{4}$ Gauging station 28 (Junta d'Aigües, 1995)

${ }^{5}$ Ninyerola et al. (2005) 
Table 2: List of the flood marks used in the hydraulic modeling.

\begin{tabular}{|c|c|c|c|c|c|c|c|c|c|}
\hline \multirow[b]{2}{*}{$\begin{array}{l}\text { Site } \\
\text { (Fig. } \\
\text { 1) }\end{array}$} & \multirow[b]{2}{*}{ River } & \multirow[b]{2}{*}{ Site } & \multirow[b]{2}{*}{ Location } & \multirow[b]{2}{*}{$\begin{array}{l}\text { Type of } \\
\text { mark }\end{array}$} & \multicolumn{3}{|c|}{ UTM Coordinates (ETRS89, UTM 31T) } & \multirow[b]{2}{*}{ Reliability $^{3}$} & \multirow[b]{2}{*}{$\begin{array}{l}\text { Precision } \\
(\mathrm{cm})\end{array}$} \\
\hline & & & & & $\begin{array}{l}\mathrm{X} \\
(\mathrm{m})\end{array}$ & $\begin{array}{l}\mathrm{Y} \\
(\mathrm{m})\end{array}$ & $\mathrm{Z}(\mathrm{m})$ & & \\
\hline 1 & \multirow[t]{2}{*}{ Sió } & $\begin{array}{l}\text { Mont- } \\
\text { roig }\end{array}$ & $\begin{array}{l}\text { Molí } \\
\text { del } \\
\text { Serra }\end{array}$ & $\begin{array}{l}\text { Incision } \\
\text { on a } \\
\text { column }\end{array}$ & 348614 & 4624073 & 377.68 & 3 & \pm 10 \\
\hline 2 & & Agramunt & $\begin{array}{l}\text { Mediaeval } \\
\text { bridge }\end{array}$ & Plaque & 341898 & 4627625 & 330.03 & 2 & \pm 30 \\
\hline 3 & Ondara & Cervera & $\begin{array}{l}\text { Molí } \\
\text { del } \\
\text { Grau }\end{array}$ & $\begin{array}{l}\text { Written } \\
\text { refer- } \\
\text { ence }^{1}\end{array}$ & 355352 & 4613639 & 461.94 & 3 & \pm 30 \\
\hline
\end{tabular}




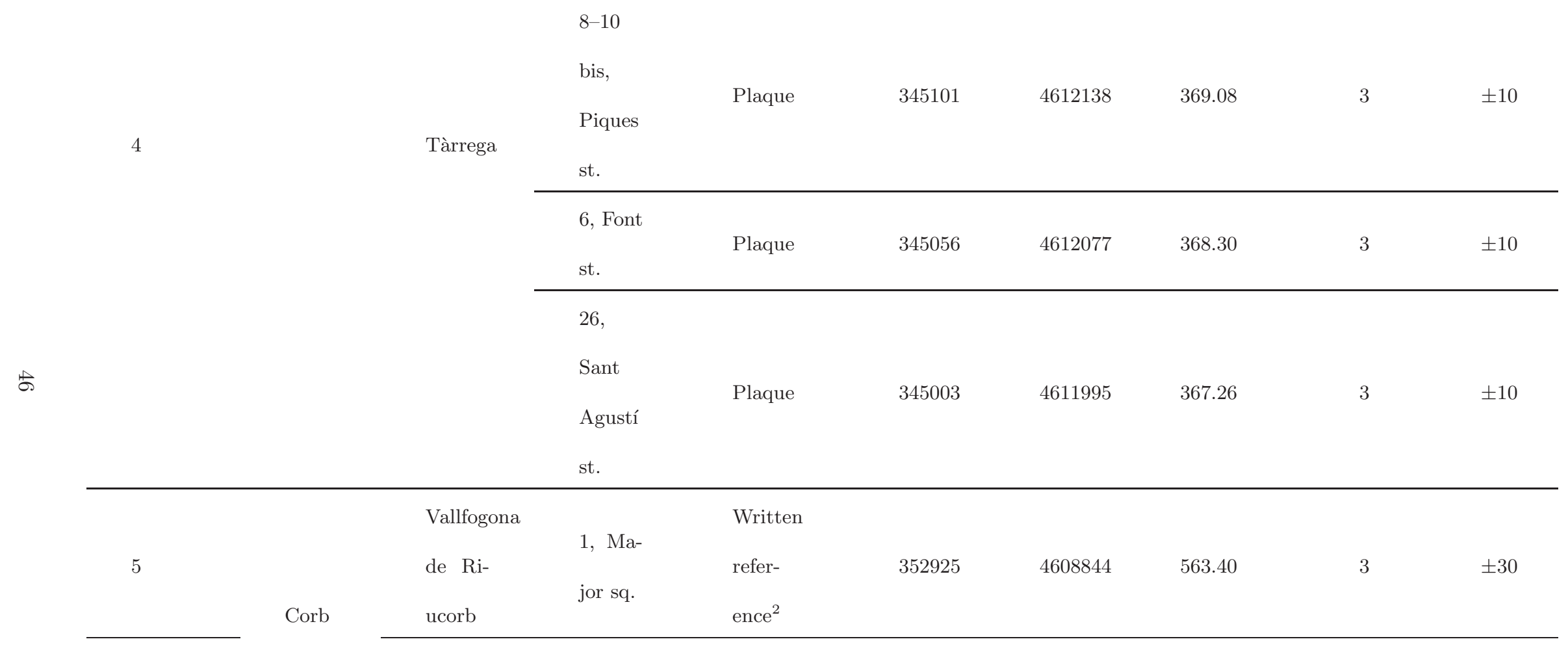




\begin{tabular}{|c|c|c|c|c|c|c|c|c|c|}
\hline 6 & & Guimerà & $\begin{array}{l}\text { Piques } \\
\text { st. }\end{array}$ & Plaque & 348733 & 4602951 & 507.57 & 3 & \pm 10 \\
\hline 7 & & Ciutadilla & $\begin{array}{l}\text { Hostal } \\
\text { del } \\
\text { Teuler }\end{array}$ & Plaque & 344061 & 4603095 & 464.01 & 3 & \pm 10 \\
\hline 8 & $\begin{array}{l}\text { Vall } \\
\text { Ma- } \\
\text { jor }\end{array}$ & $\begin{array}{l}\text { Granyena } \\
\text { de les } \\
\text { Gar- } \\
\text { rigues }\end{array}$ & $\begin{array}{l}\text { Molí } \\
\text { de la } \\
\text { Soci- } \\
\text { etat }\end{array}$ & $\begin{array}{l}\text { Incision } \\
\mathrm{N} \text { cor- } \\
\text { ner }\end{array}$ & 303.646 & 4589302 & 312.08 & 3 & \pm 10 \\
\hline 9 & Francolí & $\begin{array}{l}\text { Espluga } \\
\text { de } \\
\text { Fran- } \\
\text { colí }\end{array}$ & $\begin{array}{l}\text { Font } \\
\text { Major }\end{array}$ & Plaque & 341355 & 4584783 & 408.68 & 3 & \pm 10 \\
\hline
\end{tabular}




\begin{tabular}{|c|c|c|c|c|c|c|c|c|}
\hline \multirow[b]{2}{*}{10} & \multirow[b]{2}{*}{ Montblanc } & Molí & \multicolumn{2}{|c|}{ Plaque } & \multirow[b]{2}{*}{4580138} & \multirow[b]{2}{*}{295.47} & \multirow[b]{2}{*}{3} & \multirow[b]{2}{*}{ \pm 10} \\
\hline & & de la & SW & 347865 & & & & \\
\hline & & Farga & corner & & & & & \\
\hline
\end{tabular}

\footnotetext{
${ }^{1}$ Corbella (2003)

${ }^{2}$ Xuclà (1977)

${ }^{3}$ Reliability according to the scale proposed by Bayliss \& Reed (2001): $1=$ unreliable; $2=$ reliable; $3=$ very reliable

${ }^{4}$ Precision: maximum expected difference in $\mathrm{cm}$ between the flood mark and the actual maximum water height
} 
Table 3: Changes in the modeled reaches.

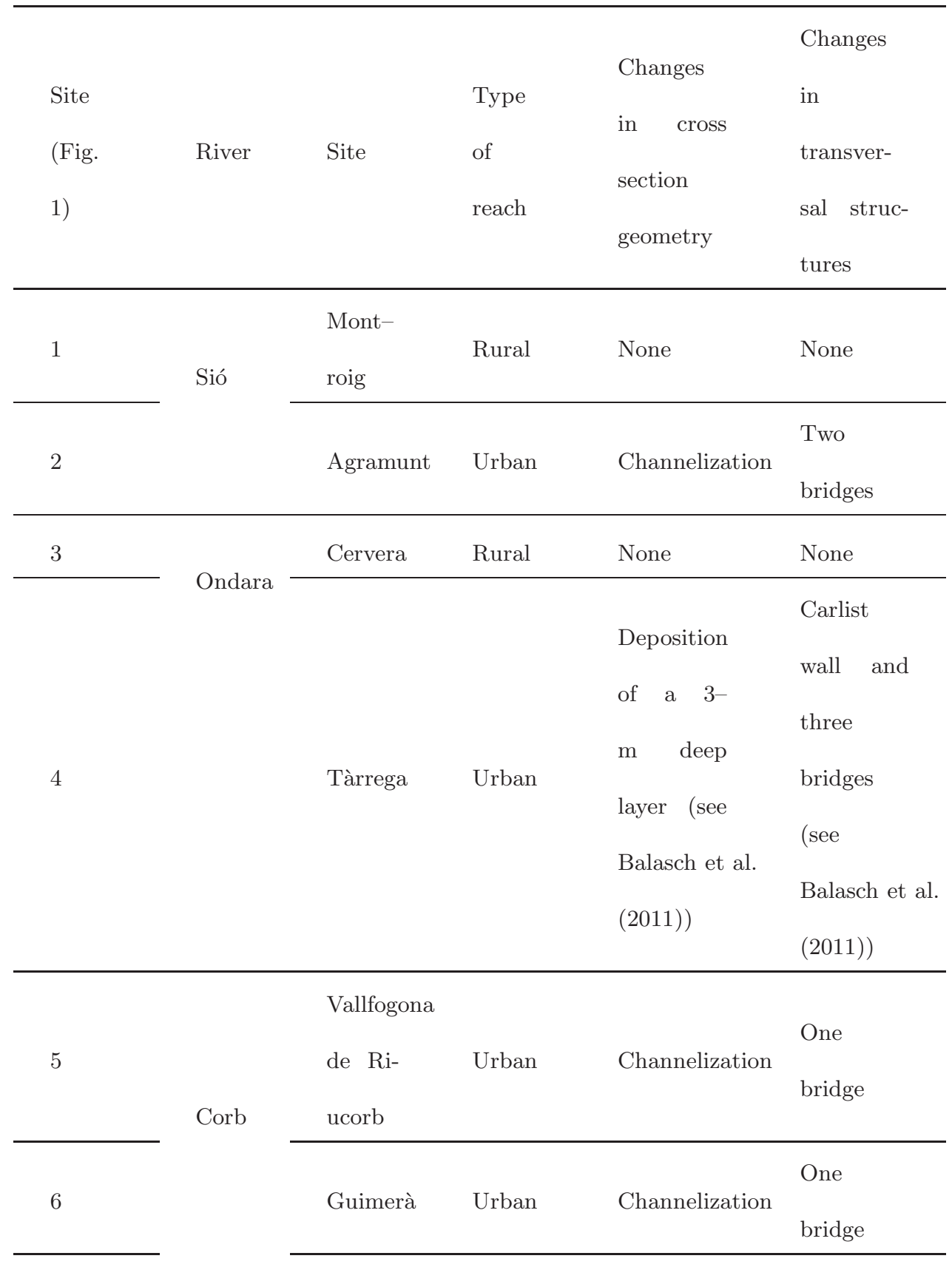




\begin{tabular}{|c|c|c|c|c|c|}
\hline 7 & & Ciutadilla & Rural & None & $\begin{array}{l}\text { One } \\
\text { bridge }\end{array}$ \\
\hline 8 & $\begin{array}{l}\text { Vall } \\
\text { Ma- } \\
\text { jor }\end{array}$ & $\begin{array}{l}\text { Granyena } \\
\text { de les } \\
\text { Gar- } \\
\text { rigues }\end{array}$ & Rural & None & None \\
\hline 9 & Francolí & $\begin{array}{l}\text { Espluga } \\
\text { de } \\
\text { Fran- } \\
\text { colí }\end{array}$ & Urban & None & None \\
\hline 10 & & Montblanc & Rural & None & None \\
\hline
\end{tabular}


Table 4: Destroyed and damaged structural elements in Urgell County and in the whole Catalonia. Own elaboration from various sources (Diario de Barcelona, 1874; Salvadó, 1875; Pleyán de Porta, 1945; Iglésies, 1971; Piqué, 1986; Coma, 1990; Vila, 1992; Espinagosa et al., 1996).

\begin{tabular}{ccc}
\hline Structural element & Urgell county & Catalonia \\
\hline Destroyed buildings & $>406$ & 564 \\
\hline Damaged buildings & $>290$ & 317 \\
\hline Bridges & 1 & 24 \\
\hline Mills & 15 & 32 \\
\hline Roads & No data & 5 \\
\hline Railroads & 2 & 5 \\
\hline Factories & 4 & 6 \\
\hline Warehouses & Several & 4 \\
\hline Irrigation infrastructures & All & 3 \\
\hline Total destroyed elements & 452 & 643 \\
\hline
\end{tabular}


Table 5: Results of the hydraulic modeling at the ten sites.

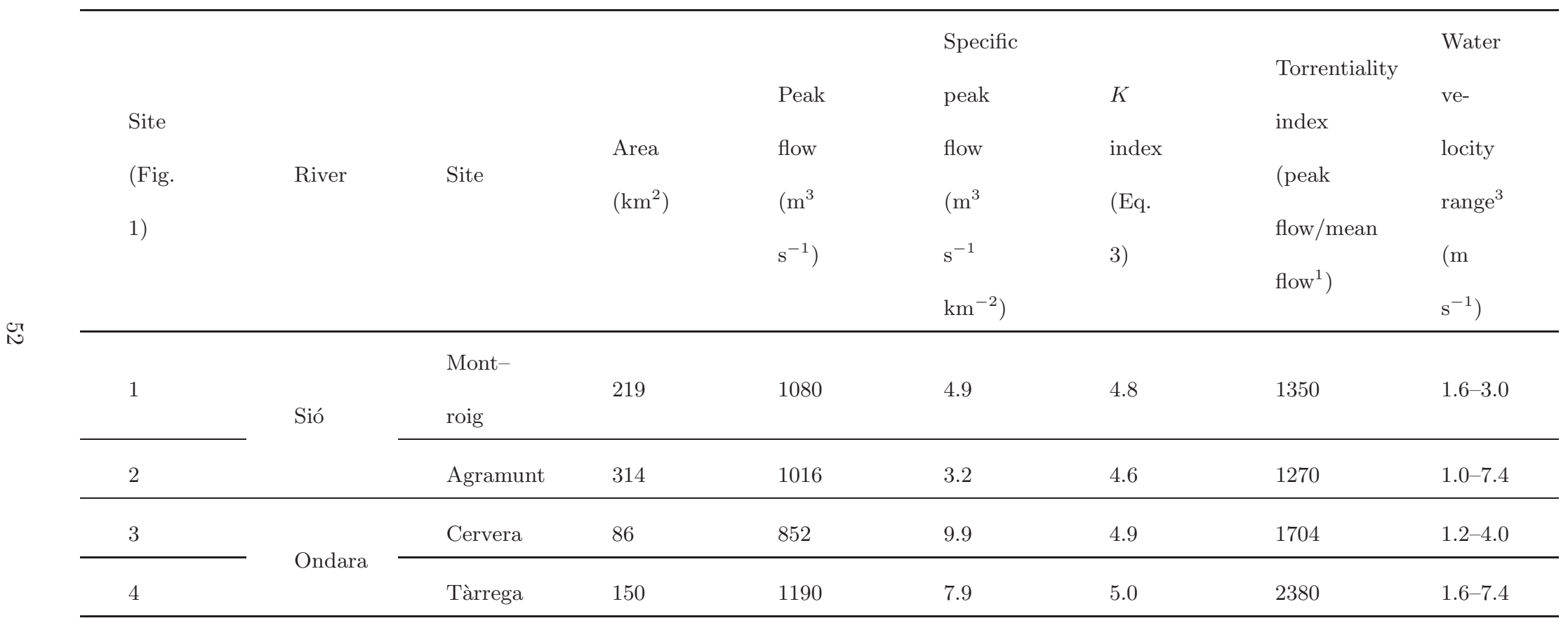




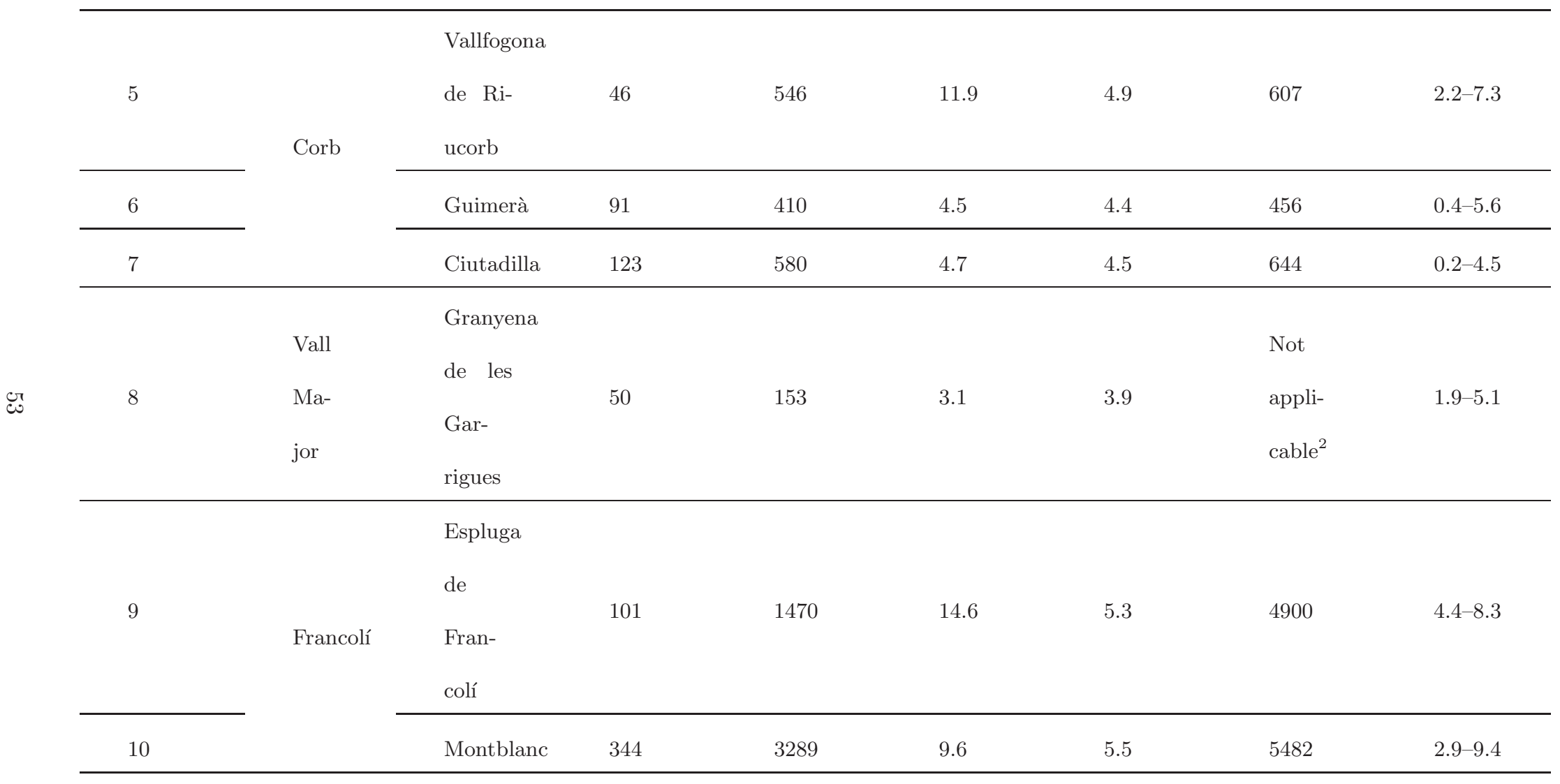


${ }^{1}$ Mean flow found in Table

${ }^{2}$ Not applicable because mean flow is $0 \mathrm{~m}^{3} \mathrm{~s}^{-1}$

${ }^{3}$ Minimum and maximum water velocity in the channel along the modeled reach 
Table 6: Series of reconstructed flows of historical floods. Source (Balasch et al., 2011).

\begin{tabular}{cc}
\hline Year & Peak flow $\left(\mathrm{m}^{3} \mathrm{~s}^{-1}\right)$ \\
\hline 1615 & 790 \\
\hline 1644 & 1600 \\
\hline 1783 & 490 \\
\hline 1842 & 210 \\
\hline 1874 & 1190 \\
\hline 1930 & 280 \\
\hline 1989 & 260 \\
\hline
\end{tabular}


Table 7: Results of the sensitivity analysis of the hydraulic modeling.

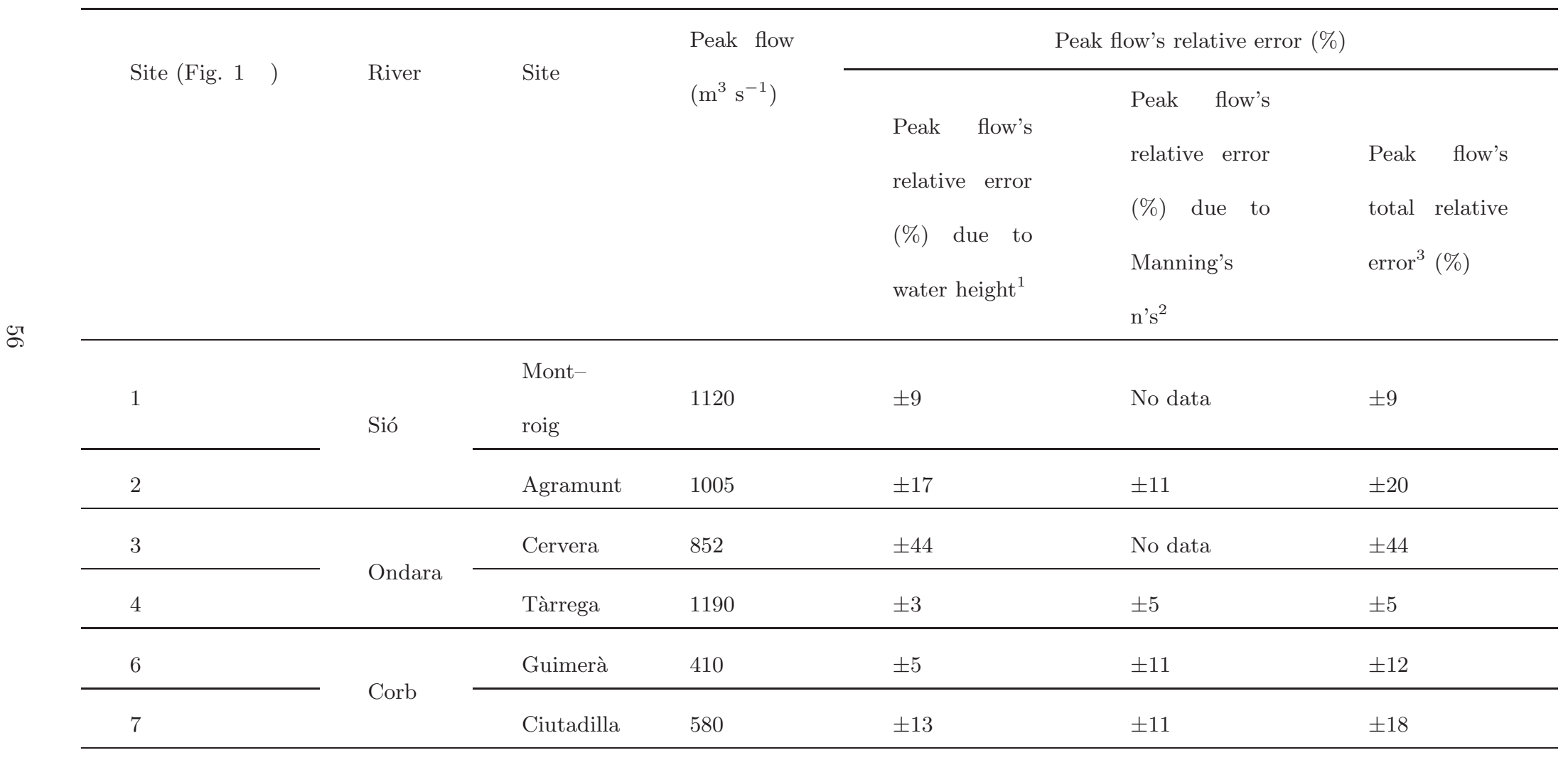


${ }^{1}$ Peak flow's relative error supposing an error in water height of $\pm 30 \mathrm{~cm}$ in Agramunt and Cervera and $\pm 10 \mathrm{~cm}$ in the other sites (Table 2.)

${ }^{2}$ Peak flow's relative error supposing an error of $\pm 30 \%$ in Manning's $n$

${ }^{3}$ Quadratic sum (Eq. 1) of the relative errors due to water height and (when calculated) Manning's n 
Table 8: Results of the hydrological modeling at five of the ten sites.

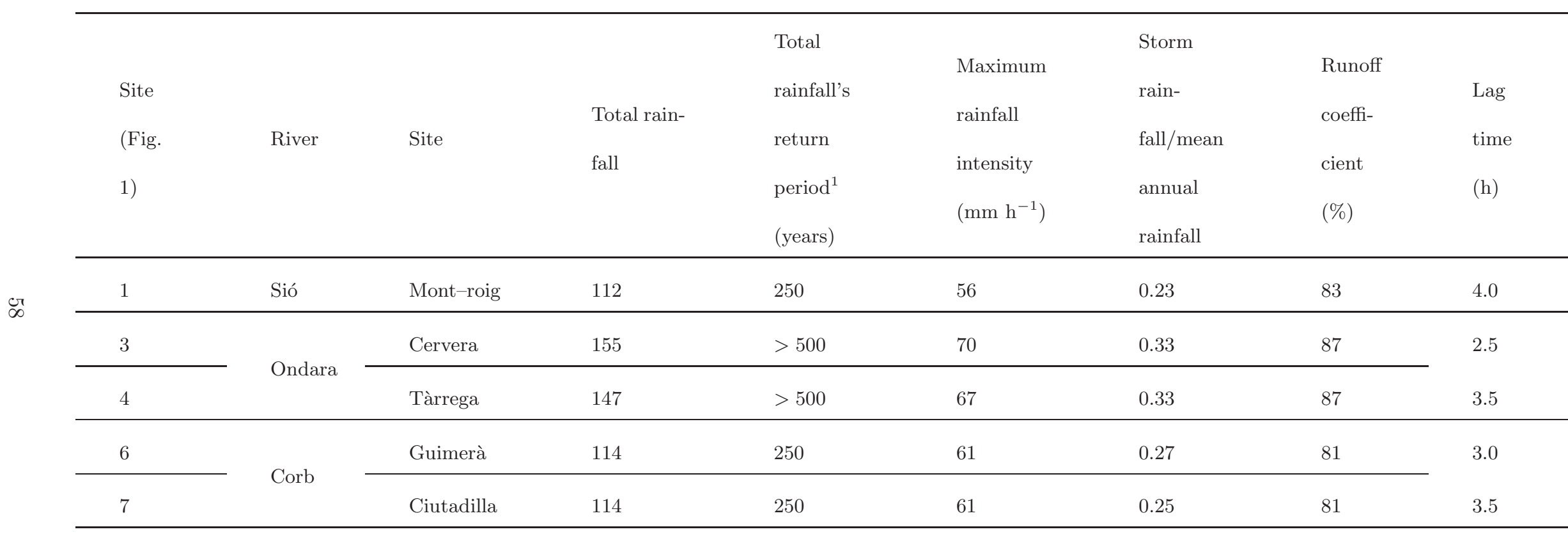

\footnotetext{
${ }^{1}$ Approximate return periods from maps by Casas (2005)

${ }^{2}$ Mean annual rainfall found in Table 1.
} 
Table 9: Hyetographs of total and effective rain in Sió, Ondara and

Corb catchments, with their mean Curve Number and their antecedent

soil moisture condition.

\begin{tabular}{|c|c|c|c|c|c|c|}
\hline & \multicolumn{2}{|c|}{ Sió River catchment } & \multicolumn{2}{|c|}{ Ondara River catchment } & \multicolumn{2}{|c|}{ Corb River catchment } \\
\hline Curve & \multicolumn{2}{|c|}{85} & \multicolumn{2}{|c|}{85.5} & \multicolumn{2}{|c|}{84.5} \\
\hline \multicolumn{7}{|l|}{ Antecedent } \\
\hline soil mois- & \multicolumn{2}{|c|}{ III (saturated) } & \multicolumn{2}{|c|}{ III (saturated) } & \multicolumn{2}{|c|}{ III (saturated) } \\
\hline \multicolumn{7}{|l|}{$\begin{array}{l}\text { ture } \\
\text { condition }\end{array}$} \\
\hline \multirow{3}{*}{ Local time } & Total & Effective & Total & Effective & Total & Effective \\
\hline & rain & rain & rain & rain & rain & rain \\
\hline & $(\mathrm{mm})$ & $(\mathrm{mm})$ & $(\mathrm{mm})$ & $(\mathrm{mm})$ & $(\mathrm{mm})$ & $(\mathrm{mm})$ \\
\hline 09:00 pm & 2.4 & 0.0 & 2.9 & 0.0 & 0.0 & 0.0 \\
\hline
\end{tabular}




\begin{tabular}{|c|c|c|c|c|c|c|}
\hline 10:00 pm & 33.1 & 19.5 & 26.2 & 14.6 & 0.0 & 0.0 \\
\hline $11: 00 \mathrm{pm}$ & 53.2 & 49.4 & 68.5 & 63.7 & 0.0 & 0.0 \\
\hline $\begin{array}{l}12 \text { mid- } \\
\text { night }\end{array}$ & 26.0 & 25.3 & 43.7 & 42.9 & 11.2 & 1.9 \\
\hline 01:00 am & 5.9 & 5.8 & 9.5 & 9.3 & 56.5 & 46.4 \\
\hline 02:00 am & 1.7 & 1.6 & 2.5 & 2.4 & 23.6 & 22.5 \\
\hline 03:00 am & 0.7 & 0.7 & 1.0 & 1.0 & 9.7 & 9.3 \\
\hline 04:00 am & 0.5 & 0.4 & 0.0 & 0.0 & 7.1 & 6.9 \\
\hline 05:00 am & 0.5 & 0.4 & 0.0 & 0.0 & 5.9 & 5.7 \\
\hline 06:00 am & 0.2 & 0.2 & 0.0 & 0.0 & 0.0 & 0.0 \\
\hline
\end{tabular}


Table 10: Results of the sensitivity analysis of the hydrological modeling

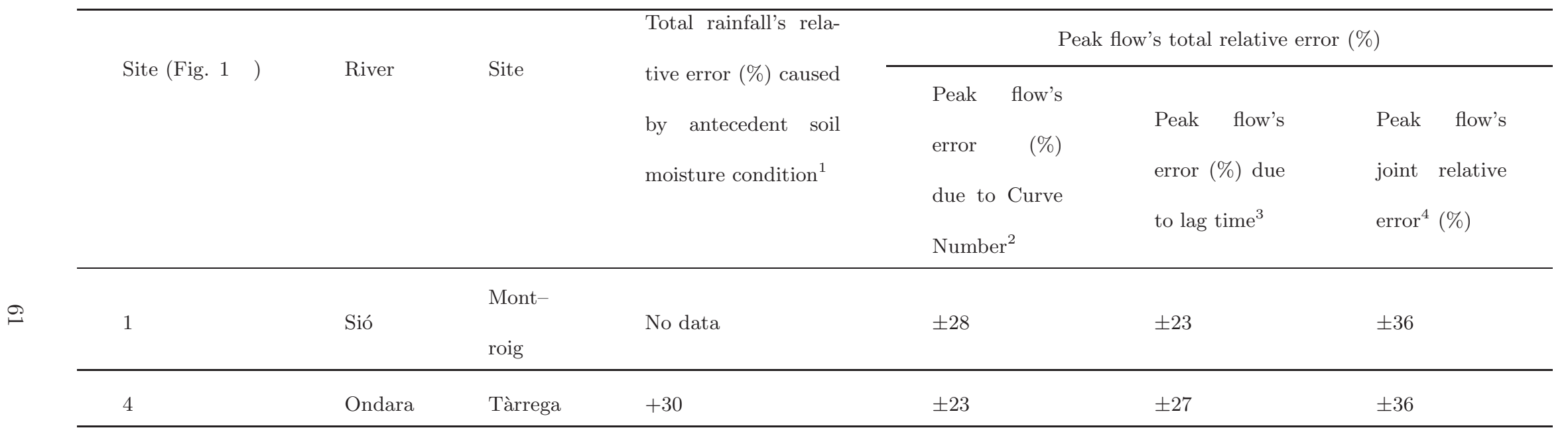

\footnotetext{
${ }^{1}$ Total rainfall's relative error if antecedent soil moisture condition had been II (intermediate) instead of III (saturated)

${ }^{2}$ Peak flow's relative error supposing an error of \pm 10 units in the Curve Number value

${ }^{3}$ Peak flow's relative error supposing an error of $\pm 40 \%$ in lag time

${ }^{4}$ Quadratic sum of the relative errors due to Curve Number and lag time
} 
Table 11: Some convective indexes over the town of Valls (Figure 1) during the rainstorm occurred on 23 September 1874, at 00 UTC. Own elaboration from data from NCAA 20th Century Reanalysis and Grieser (2012).

\begin{tabular}{|c|c|c|}
\hline Convection index & $\begin{array}{l}\text { Convection } \\
\text { index value }\end{array}$ & $\begin{array}{l}\text { Meaning of the index value } \\
\text { Grieser (2012) }\end{array}$ \\
\hline $\begin{array}{l}\text { Convective available poten- } \\
\text { tial energy, } \operatorname{CAPE}\left(\mathrm{J} \mathrm{kg}^{-1}\right)\end{array}$ & 2546 & $\begin{array}{l}\text { CAPE }>2500 \mathrm{~J} \mathrm{~kg}^{-1} \rightarrow \\
\text { strong instability }\end{array}$ \\
\hline Lifted index, LI (K) & -11 & $\begin{array}{l}\mathrm{LI} \leq-6 \mathrm{~K} \rightarrow \text { severe thun- } \\
\text { derstorms likely }\end{array}$ \\
\hline K-index, KI (K) & 33 & $\begin{array}{l}31 \leq \mathrm{KI} \leq 35 \rightarrow 60-80 \% \\
\text { thunderstorm probability }\end{array}$ \\
\hline Vertical total,VT (K) & 28 & $\begin{array}{l}\mathrm{VT} \geq 26 \mathrm{~K} \rightarrow \text { thunderstorm } \\
\text { prone weather }\end{array}$ \\
\hline Cross total, CT (K) & 23.1 & $\begin{array}{l}\mathrm{CT} \geq 20 \mathrm{~K} \rightarrow \text { thunderstorm } \\
\text { prone weather }\end{array}$ \\
\hline Total total, TT (K) & 51.9 & $\begin{array}{l}\mathrm{TT} \geq 50 \mathrm{~K} \rightarrow \text { severe thun- } \\
\text { derstorms possible }\end{array}$ \\
\hline Humidity index, HI (K) & 16.5 & $\begin{array}{l}\mathrm{HI} \leq 30 \rightarrow \text { thunderstorm } \\
\text { prone weather }\end{array}$ \\
\hline $\begin{array}{l}\text { Lifting condensation level, } \\
\text { LCL }(\mathrm{m})\end{array}$ & 500 & $\begin{array}{l}\text { A good approximation of the } \\
\text { cloud base height in case of } \\
\text { forced ascend }\end{array}$ \\
\hline
\end{tabular}




\begin{tabular}{|c|c|c|}
\hline $\begin{array}{l}\text { Level of free convection, } \\
\text { LFC (m) }\end{array}$ & 500 & $\begin{array}{l}\text { LFC }<3000 \mathrm{~m} \rightarrow \text { thunder- } \\
\text { storms are more likely to be } \\
\text { initiated and maintained }\end{array}$ \\
\hline$\Delta L_{1}=\mathrm{LCL}-\mathrm{LFC}$ & 0 & $\begin{array}{l}\Delta L_{1} \text { small } \rightarrow \text { sudden deep } \\
\text { convection can occur }\end{array}$ \\
\hline $\begin{array}{l}\text { Limit of convection, LOC } \\
\text { (m) }\end{array}$ & 9500 & $\begin{array}{l}\text { Height at which convection } \\
\text { stops; clouds extend from } \\
\text { LCL to LOC; in this case, } 9 \\
\text { km high clouds, which mean } \\
\text { a high probability of rain- } \\
\text { storms }\end{array}$ \\
\hline Wind shear $1 \mathrm{~km}\left(\mathrm{~m} \mathrm{~s}^{-1}\right)$ & 1 & $\begin{array}{l}\text { Wind shear }>8 \mathrm{~m} \mathrm{~s}^{-1} \rightarrow \\
\text { supercell tornadoes }\end{array}$ \\
\hline Wind shear $3 \mathrm{~km}\left(\mathrm{~m} \mathrm{~s}^{-1}\right)$ & 6 & $\begin{array}{l}\text { Wind shear } \geq 6 \mathrm{~m} \mathrm{~s}^{-1} \rightarrow \\
\text { large and long-lasting con- } \\
\text { vection }\end{array}$ \\
\hline
\end{tabular}




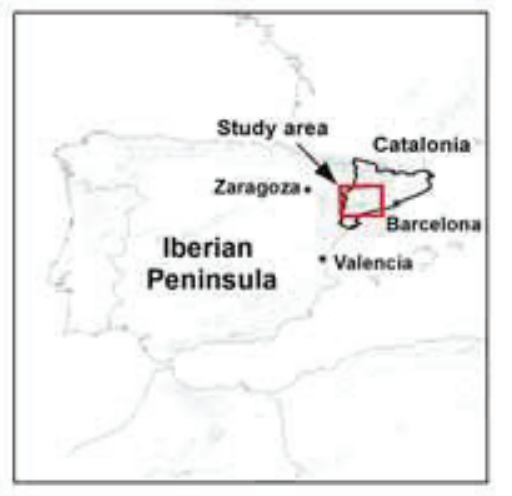

\section{Legend}

- Modeling sites

\section{Rivers}

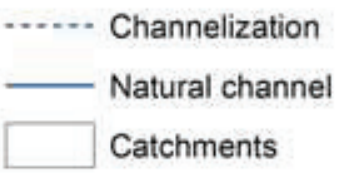

Coordinate system: ETRS 89 UTM 31 Zone T

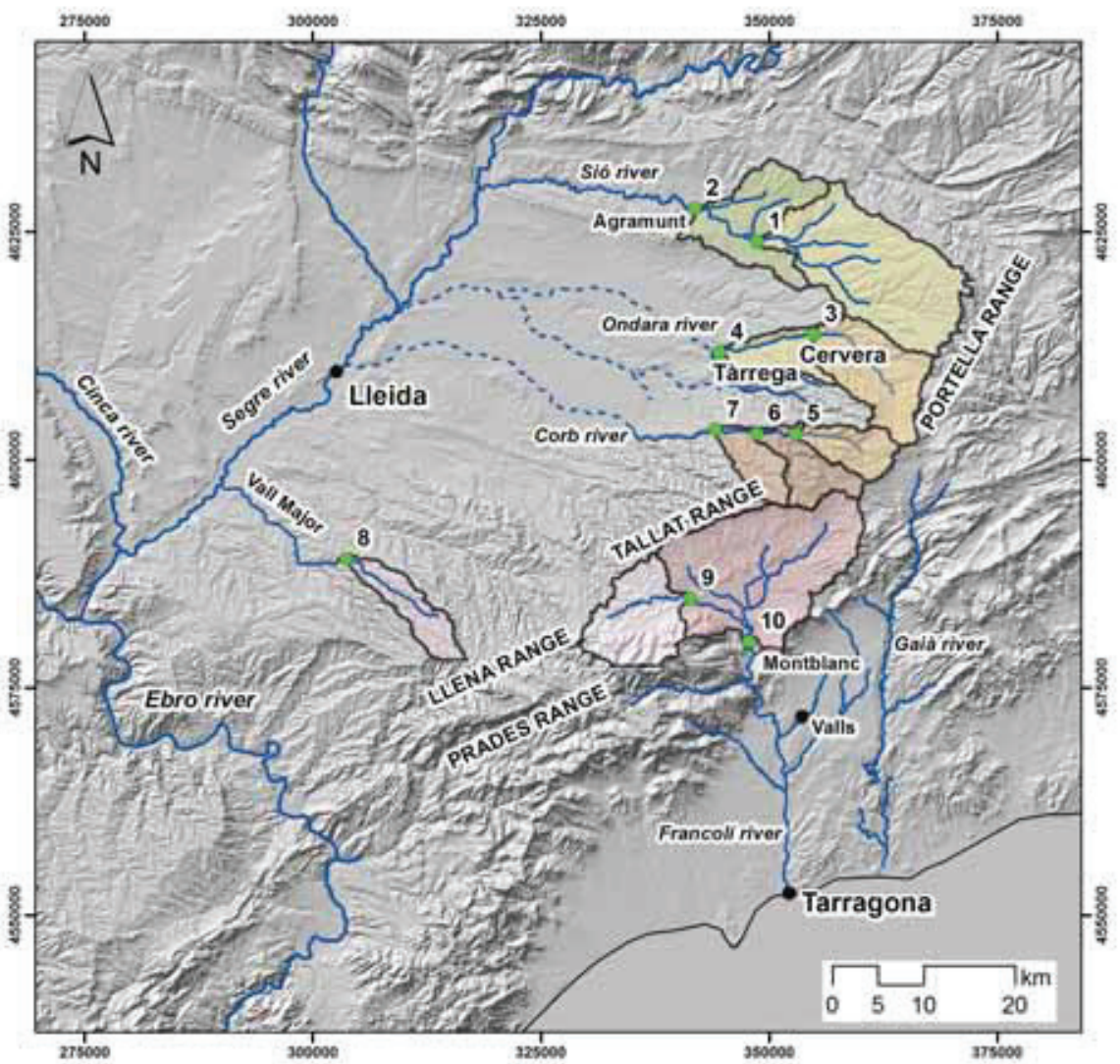

Figure 1: Location of Catalonia and the study area affected by 1874 flood within the Iberian Peninsula (small map), and location of the ten modeling sites and catchments listed in Table 1 and of the town of Valls (where convection indexes were calculated) within the affected area (large map). Maps drawn by José Antonio Martínez-Casasnovas (University of Lleida) 


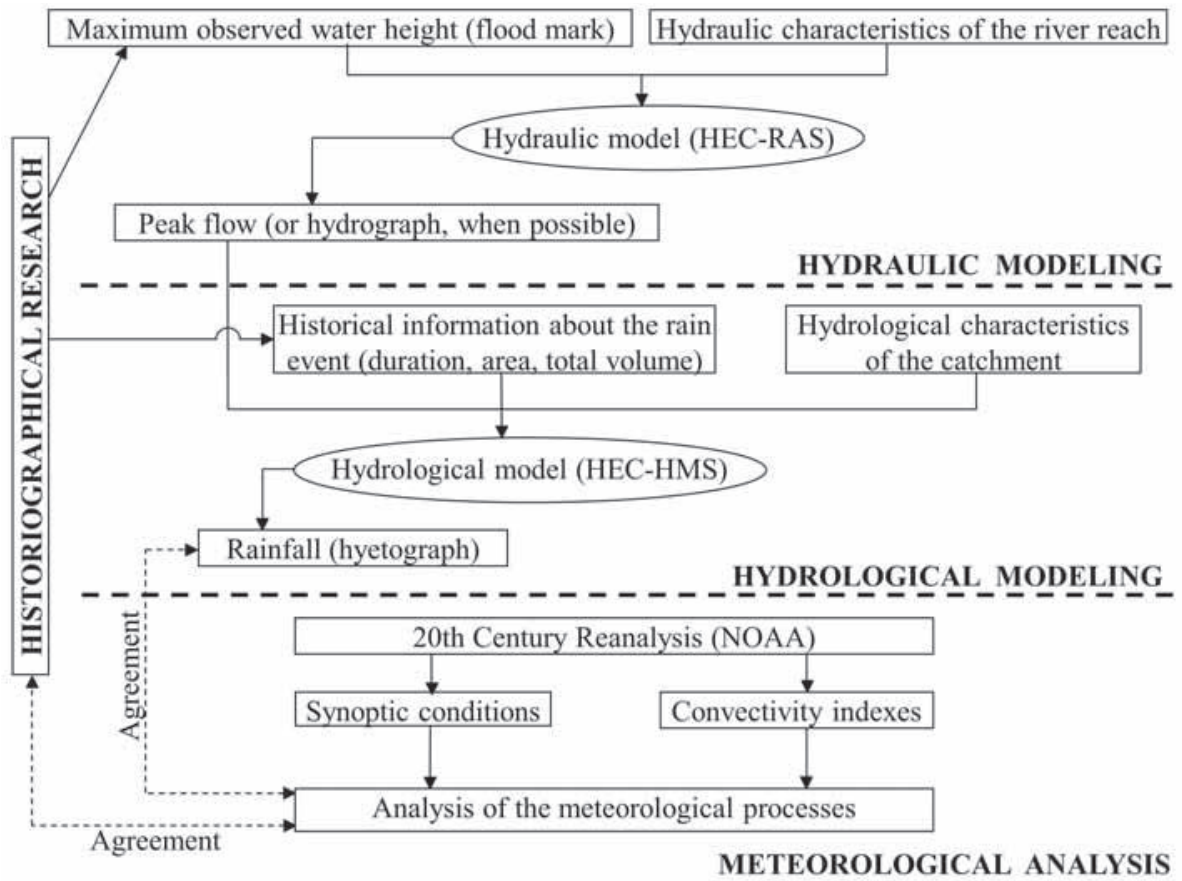

Figure 2: Diagram of the multidisciplinary procedure for historical floods reconstruction applied to 1874 Santa Tecla floods. Modified from Barriendos et al. (2014). 


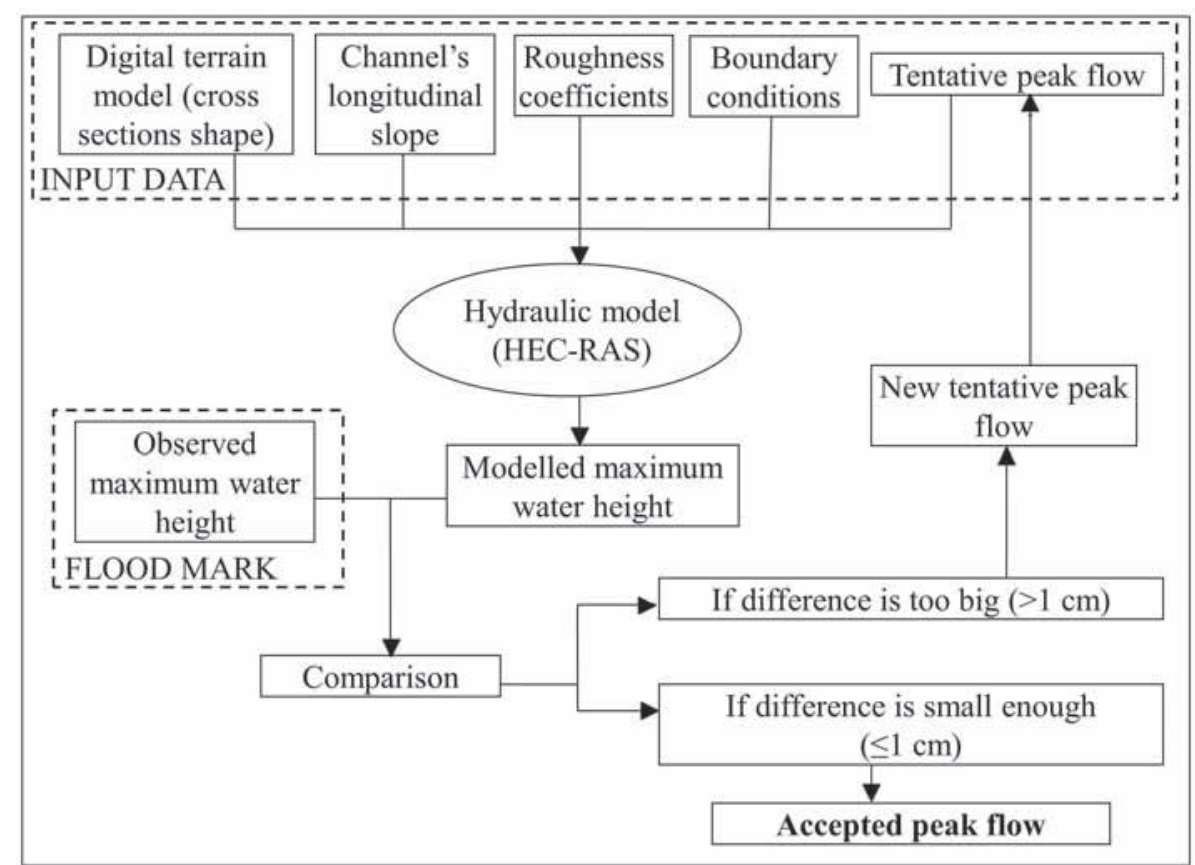

Figure 3: Diagram of the hydraulic modeling. Modified from Balasch et al. (2010b). 


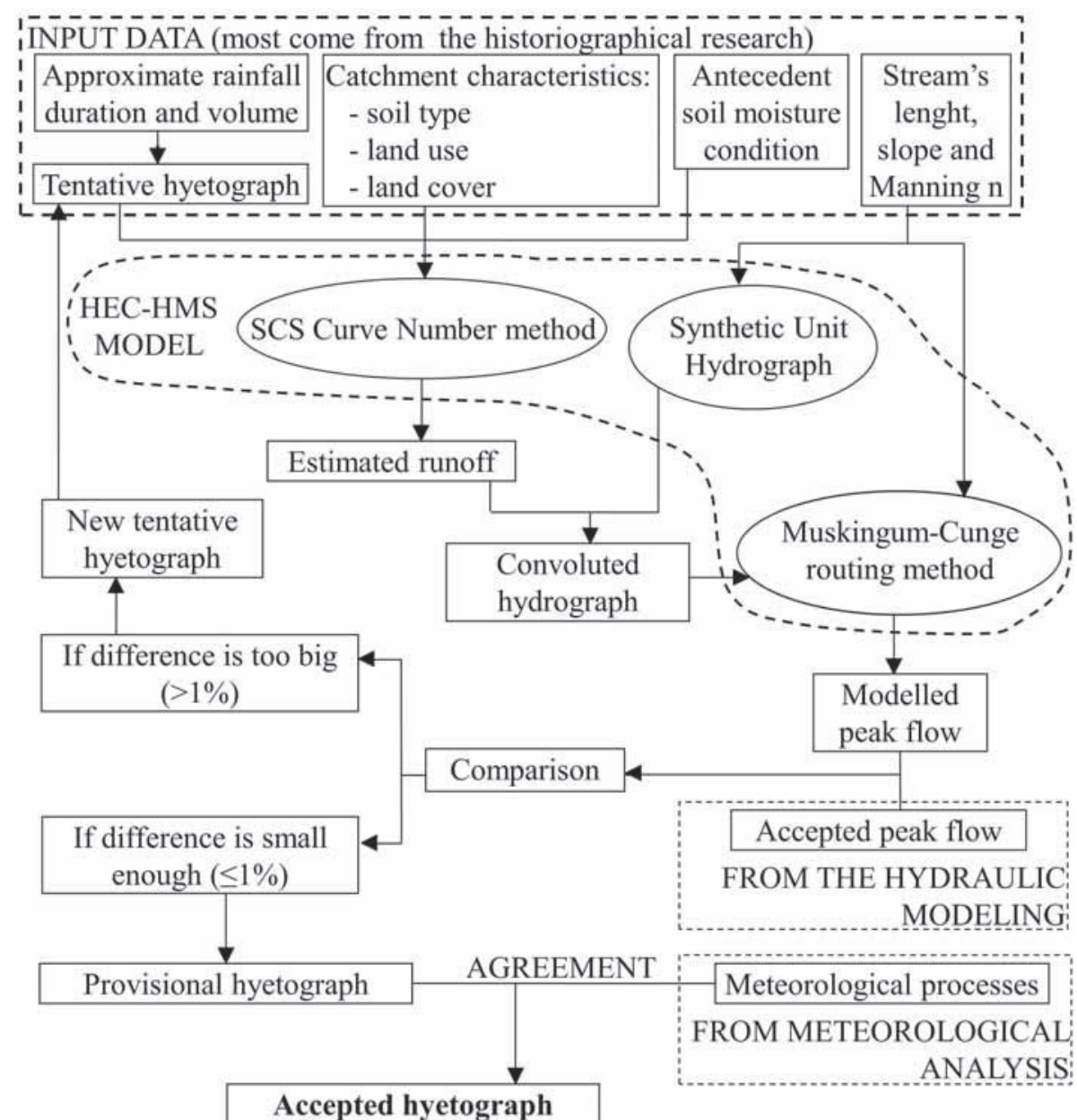

Figure 4: Diagram of the hydrological modeling. Modified from Balasch et al. (2010b). 


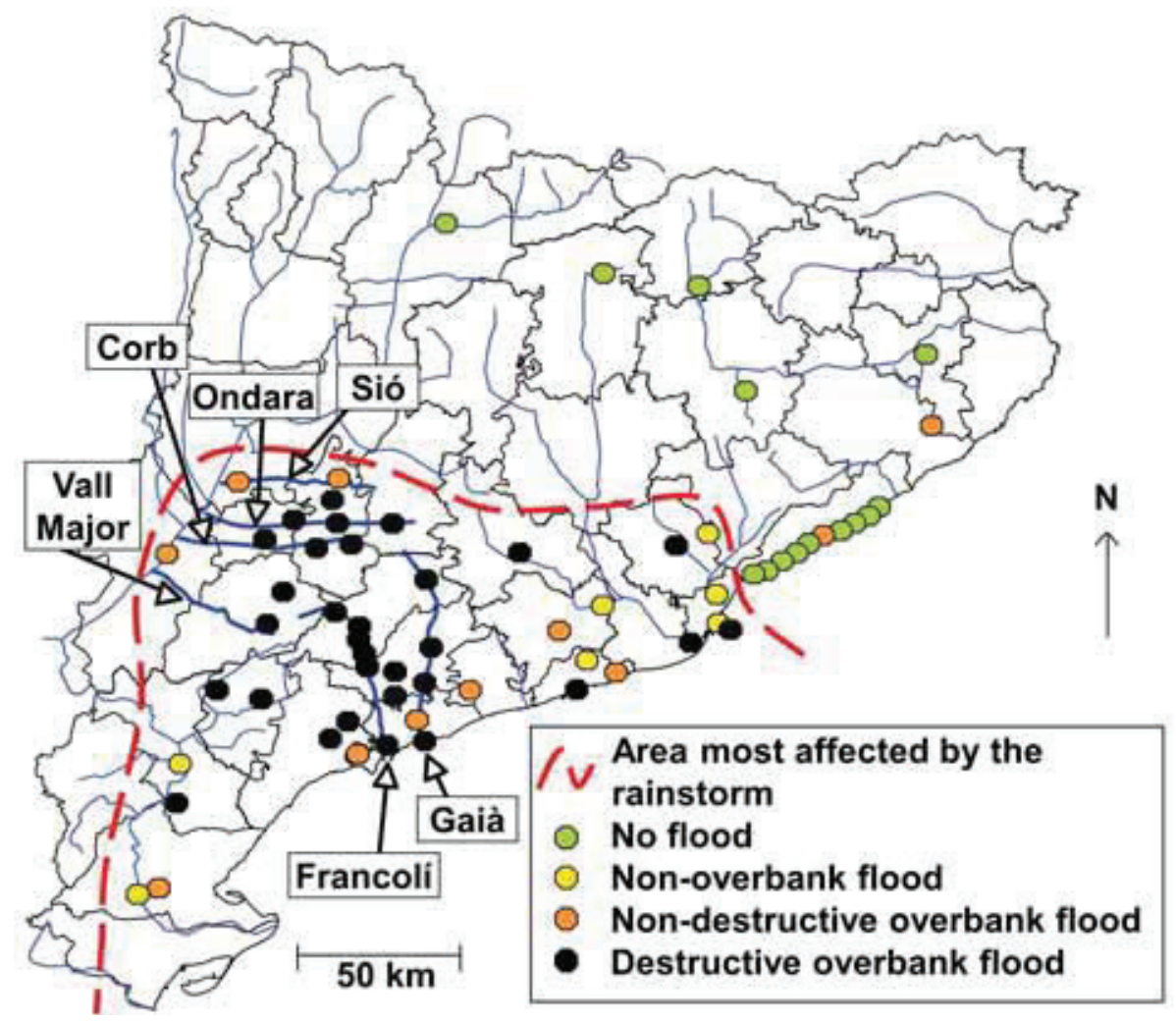

Figure 5: Map of Catalonia highlighting the area most severely affected by the 1874 floods and the sites where information about them was found. Modified from Barriendos et al. (2013). 


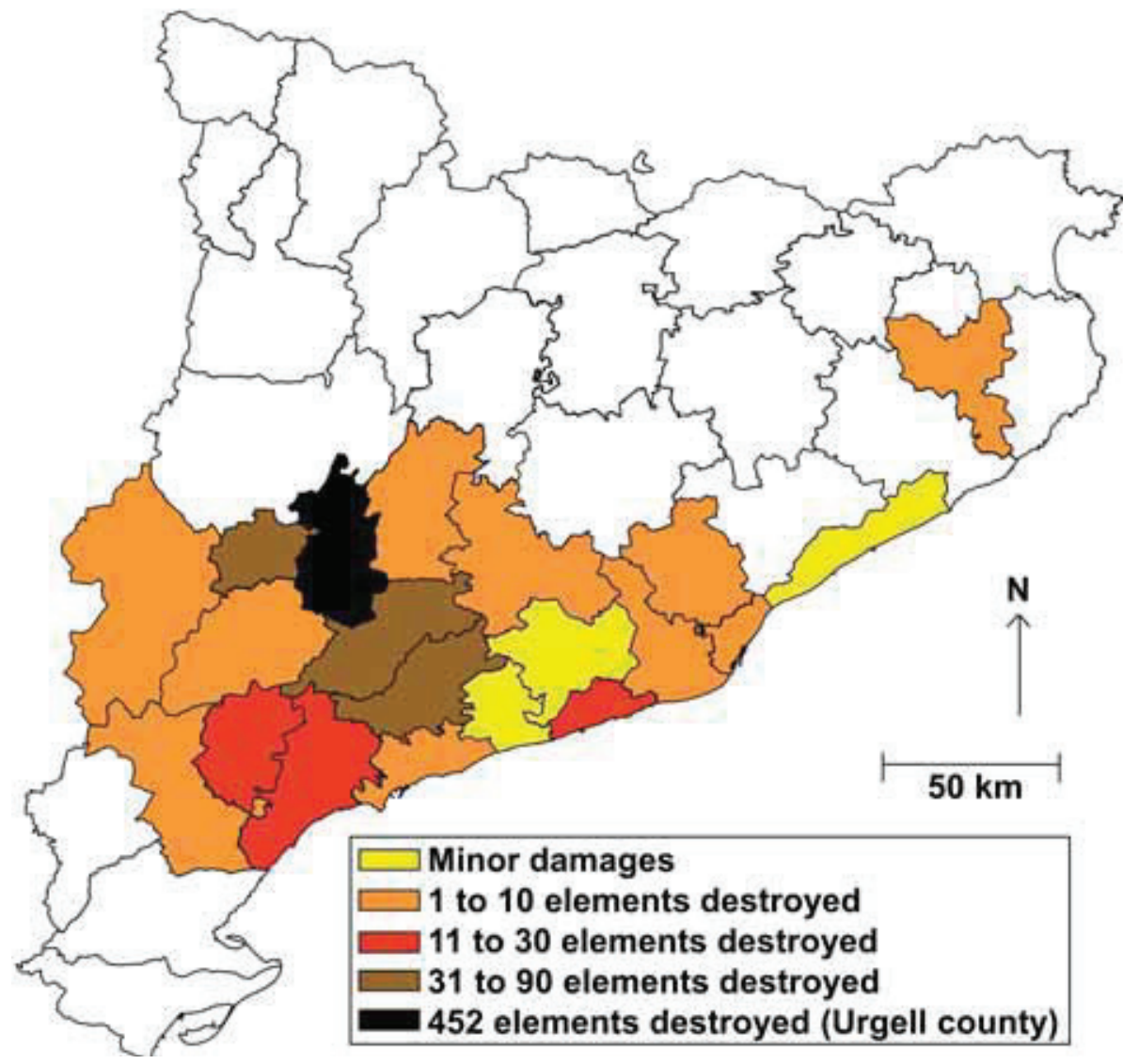

Figure 6: Map of Catalonia with the number of destroyed structural elements by county; this includes dwellings, bridges, canals, mills and all kinds of infrastructures and buildings. Modified from Barriendos et al. (2013). 


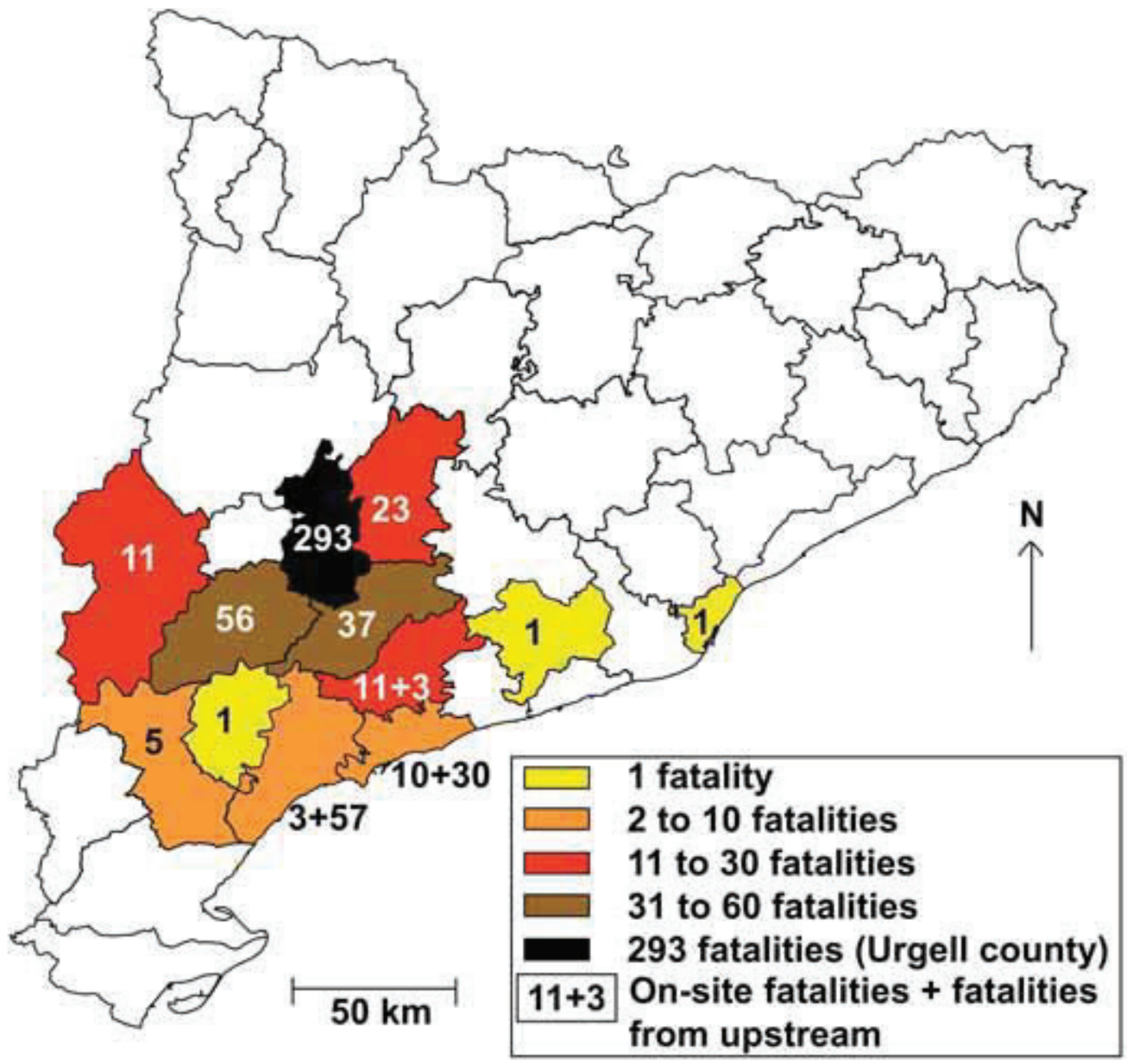

Figure 7: Map of Catalonia with the number of casualties by county. 'Fatalities from upstream' refer to people who were washed downstream by the flood. Modified from Barriendos et al. (2013). 


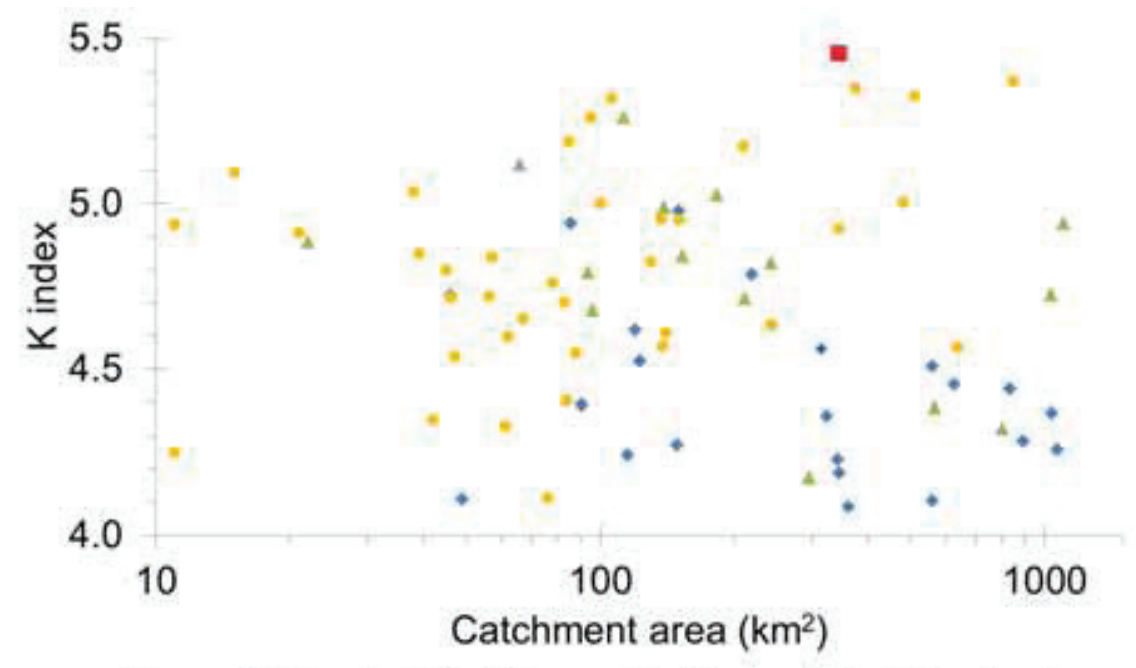

- Francoli River in Montblanc - Catchments in Ebro basin - Other Iberian catchments -French catchments

Figure 8: $K$ index of the reconstructed peak flow of 1874 Santa Tecla flood in Francolí River in Montblanc compared to those of the major floods in small Mediterranean catchments (10 to $1200 \mathrm{~km}^{2}$ ) of the Iberian Peninsula and southern France. Own elaboration with data from López-Bustos (1981); Llasat et al. (2003); Delrieu et al. (2005); Lang \& Coeur (2014); Nguyen et al. (2014). 

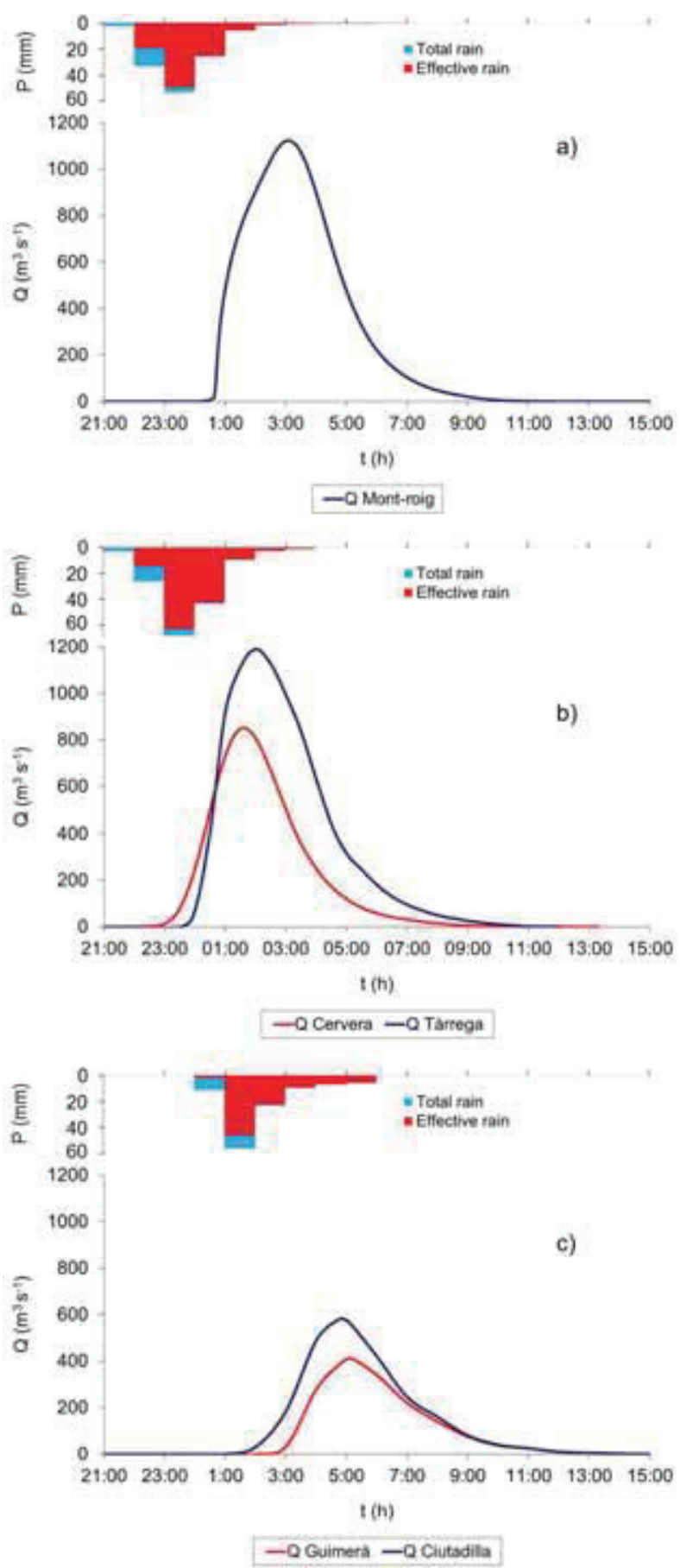

Figure 9: Hydrographs and hyetographs of Sió River at Mont-roig (a), of Ondara River at Cervera and Tàrrega (b), and Corb River at Guimerà and Ciutadilla (c). Modified from Balasch et al. (2010b). 


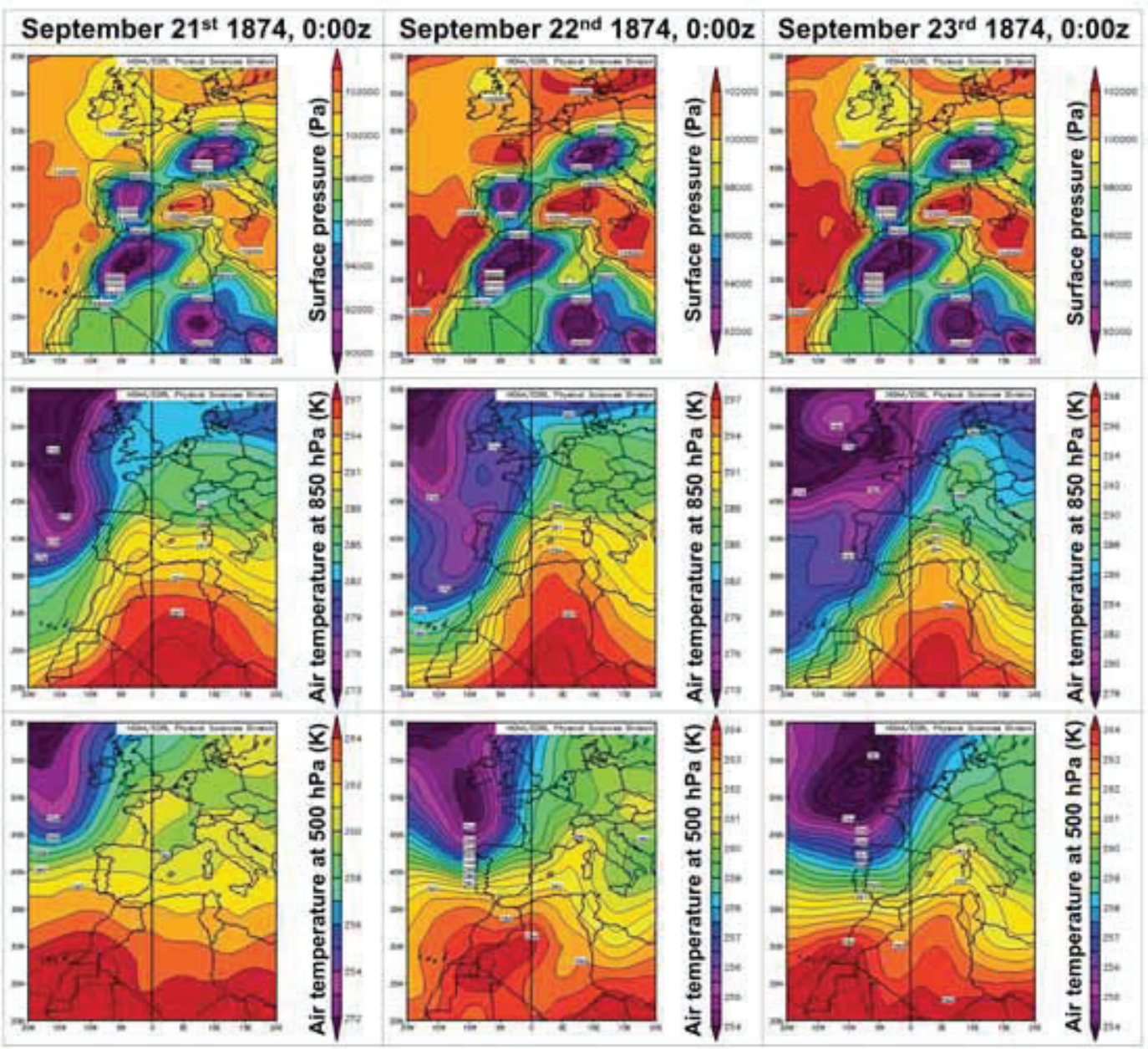

Figure 10: Synoptic conditions 48, 24, and 0 hours before Santa Tecla storm, occurred around midnight 23 September 1874. Upper map: pressure at sea level (in Pa); middle map: air temperature (in K) at a height of $850 \mathrm{hPa}$ (approx. $1500 \mathrm{~m}$ ); bottom map: air temperature (in K) at a height of $500 \mathrm{hPa}$ (approx. $5500 \mathrm{~m}$ ). Source: NOAA's 20th Century Reanalysis. 


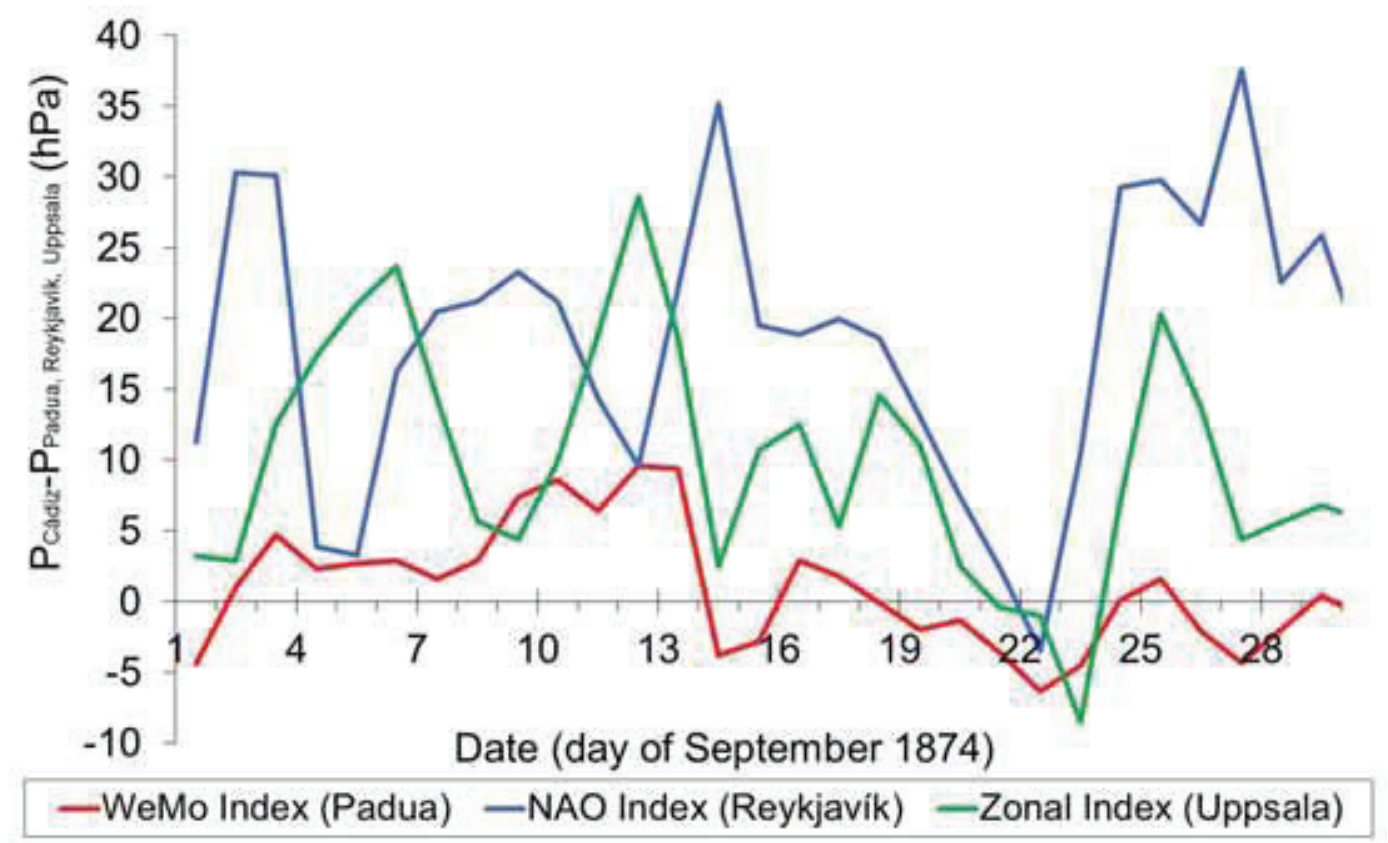

Figure 11: Pressure indexes (or surface pressure differences between two locations): WeMo (between Cádiz and Padua); NAO (between Cádiz and Reykjavk); and a zonal index (between Cádiz and Uppsala). Note: measurements taken approximately at noon local time daily. 

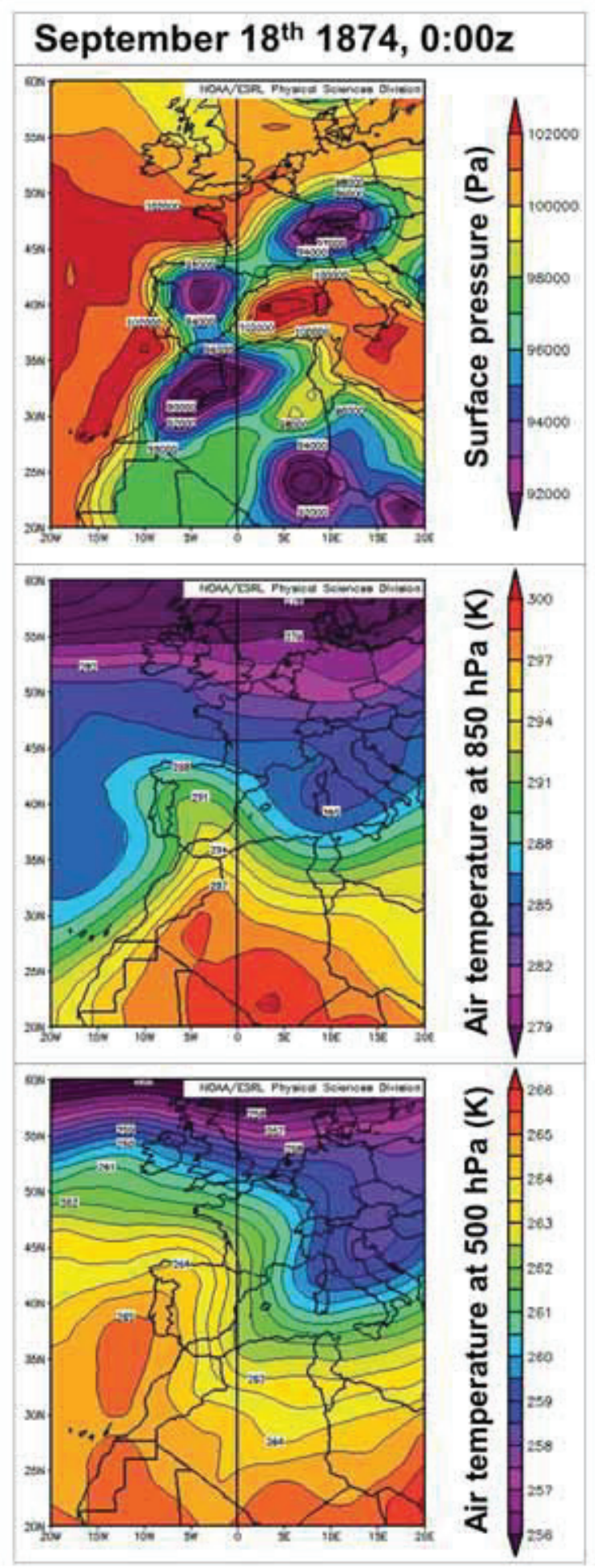

75

Figure 12: Synoptic conditions around midnight 18 September 1874, five days before Santa Tecla floods. Upper map: pressure at sea level (in $\mathrm{Pa}$ ); middle map: air temperature (in $\mathrm{K}$ ) at a height of $850 \mathrm{hPa}$ (approx. $1500 \mathrm{~m}$ ); bottom map: air temperature (in $\mathrm{K}$ ) at a height of $500 \mathrm{hPa}$ (approx. $5500 \mathrm{~m}$ ). Source: NOAA's 20th Century Reanalysis. 